\title{
Do Workers in Chile Choose Informal Employment? A Dynamic Analysis of Sector Choice*
}

By

\author{
Truman G. Packard \\ Senior Economist, Social Protection
}

The World Bank

\begin{abstract}
The degree to which a labor market is segmented and jobs in the formal sector of the economy are rationed is critical to the analysis of coverage of social insurance and pensions. In Chile, using unique panel data spanning the 1998-1999 contraction, I find little evidence that self-employment is the residual sector of a dualistic labor market, as is often depicted in the literature. Data on transitions between sectors show that selfemployment is not a free-entry sector, and that entrepreneurs can be "pushed" out of selfemployment just as others are pushed out of formal employment during economic downturns. However, employment without a contract does exhibit many of the features of the free-entry, employment safety net depicted in the dualistic literature. An annex to this paper, presents supportive evidence from static analysis of selection-corrected wage differentials, and a comment on the drawbacks of this approach.
\end{abstract}

World Bank Policy Research Working Paper 4232, May 2007

The Policy Research Working Paper Series disseminates the findings of work in progress to encourage the exchange of ideas about development issues. An objective of the series is to get the findings out quickly, even if the presentations are less than fully polished. The papers carry the names of the authors and should be cited accordingly. The findings, interpretations, and conclusions expressed in this paper are entirely those of the authors. They do not necessarily represent the view of the World Bank, its Executive Directors, or the countries they represent. Policy Research Working Papers are available online at http://econ.worldbank.org.

\footnotetext{
${ }^{*}$ The sections reviewing the literature on labor markets in developing countries, motivates the analysis of earnings differentials presented in the Appendix. The results presented in the Appendix, in turn complement the empirical sections of this paper. I would like to thank Geeta Kingdon and Abigail Barr for valuable discussions and guidance in the structuring of this paper. Adriaan Kalwij and Rosa Fernandez, Caterina Ruggeri-Laderchi and Claudio Montenegro also provided excellent suggestions.
} 


\section{Introduction}

Are workers in developing countries employed in the informal sector of the economy by chance or by choice? The answer to this question, long debated in the literature on labor economics, is also critical to the analysis of income security in retirement and to social security policy more generally, with important implications for growth and equity (World Bank, 2006). In many developing countries salaried workers are mandated to save for retirement in national social insurance systems, while the self-employed - often the largest segment of the informal economy - are left to choose whether to save and in what form. Where governments enforce this type of partial mandate to participate in social insurance - usually due to the difficulty of enforcing contributions from the selfemployed - whether workers are covered by the system can be largely determined by where they work. Further, workers who seek to avoid contributing to social insurance out of moral hazard, a strong preference for present consumption, or in favor of more flexible forms of private savings and investment for retirement - may strategically choose self-employment or unregulated wage employment to escape the mandate.

In Latin America and the Caribbean 25 countries require that all salaried workers contribute to social insurance. Of these, only 13 countries require self-employed workers to pool risks or save along with the rest of the working population. Ten countries allow the self-employed to contribute on a voluntary basis. However, even where there is an obligation to contribute to social insurance, limited monitoring and enforcement capacity allows large segments of workers to evade. ${ }^{1}$

If workers choose the sector in which they work, and the option of "formal" salaried employment is not limited by barriers to entry, policy makers in developing countries concerned with limited coverage of social insurance should turn their attention to other detriments to securing an adequate income for old age, such as individuals' myopia,

\footnotetext{
${ }^{1}$ The self-employed are required to contribute to national social insurance systems in Argentina, Brazil, Uruguay, Venezuela, Honduras and Cuba. Almost all the countries in the Caribbean also require that the self-employed participate, with the exception of Antiga and Barbuda. Participation of the self-employed is voluntary in Bolivia, Chile, Colombia, Costa Rica, Ecuador, El Salvador, Mexico, Nicaragua, Panama and Peru (Mesa-Lago, 2000).
} 
incomplete or missing capital and insurance markets, and the erosion of household savings by inflation. However, if formal jobs are rationed - either because of a legislated minimum wage set above the market-clearing wage, job security provisions, or regulations that raise the cost of legal employment - concerns that large numbers of workers are employed in an uncovered, “informal” sector - forced to face the risks of unemployment, disability, sudden death and poverty in old age on their own - may be warranted.

In this paper I focus on the labor market in Chile - a middle-income country in Latin America that in 1981 replaced a large segment of its social insurance system with privately-managed, individual retirement accounts, bundled together with market insurance against losses from disability and sudden death. Wage and salaried workers are forced to contribute $13 \%$ of their earnings, while the self-employed are free to choose whether to participate in the system. Since they are individually owned by workers and managed by private, third-party service providers, the new retirement accounts should, in theory, sever the link between formal retirement income security and a worker's place of employment. However, 20 years after the reform, both self-employment and not holding a legal employment contract significantly lower the probability of contributing to the pension system (Holzmann, Packard \& Cuesta, 2001, Packard, 2002, Barr and Packard, 2000 and 2002).

Even in countries like Chile that have adopted a social insurance system based on individual accounts, knowing how the labor market functions is critical to identifying the real barriers to income security in old age. If legal salaried jobs are not rationed, and individuals choose employment in the informal sector, policy makers may be justified in expecting the self-employed and informal wage employees to take responsibility for their retirement security, whether by contributing to the national pension system or pursuing other private alternatives. Greater effort should be placed on educating workers on the need to save and on augmenting capital and insurance markets to provide better instruments for individuals and households to manage risks to income over the life-cycle. On the other hand, to the extent that workers in the informal sector are queuing along with the unemployed for formal jobs, and fail to save primarily because they are not 
employed in the sector mandated to save, policymakers should not ignore rigidities and segmentation in the labor market. Finally, if workers strategically choose to move in and out of self-employment to avoid formal retirement security, policymakers wishing to guard social insurance systems against moral hazard and adverse selection may be justified in extending the mandate to all workers (Gill, Packard and Yermo, 2004). These issues have been debated recently in Chile, and feature in current proposals to reform the pension system (World Bank, 2006).

Following the introduction, Section II reviews the literature on employment and sector choice, presenting competing views of how labor markets function in developing countries. Section III describes the empirical strategy used in this analysis and presents the hypotheses to be tested. Section IV presents historical data on employment trends in Chile and describes the variables constructed from responses to two surveys in Santiago, collected in the midst of very different macroeconomic climates. The results of maximum likelihood regression techniques are discussed in Section V and Section VI concludes.

\section{The Informal Sector and Self-Employment in Developing Countries: An Unemployment "Push" or Entrepreneurial "Pull"?}

Much of the literature on labor markets in developing countries characterizes selfemployment and unregulated wage employment as a residual, free-entry, "informal" sector where workers who have lost salaried jobs in economic downturns along with those who have recently migrated from rural areas, bide their time queuing for rationed employment in modern firms (Lewis, 1954, Harris and Todaro, 1970, Fields, 1975 and 1990, Pradhan, 1995). This traditional view characterizes labor markets as segmented and dualistic. However, several contributions to the literature suggest an alternative view: that many individuals choose to work informally, and that self-employment in particular is a sector into which agents with a lower aversion to risk, a desire for independence, and/or a greater endowment of entrepreneurial talent are likely to self-select (Knight, 1921, Laffont, 1979). Empirical evidence from both developed (Taylor, 1996, Blanchflower and Oswald, 1991 \& 1998, Uusitalo, 1999, Guiso and Paiella, 2000) and 
developing countries (Blau, 1985, Vijverberg, 1986, Yamada, 1996, Maloney, 1998a \& 1998b, Aroca and Maloney, 1999, Maloney 2004) supports the latter view.

Each characterization of the labor market leads to very different predicted outcomes and policy implications. For instance, if as is argued in the dualistic model, formal salaried jobs are rationed and the labor market is segmented by government or union imposed rigidities that push the cost of labor above the market clearing wage to where there are too few jobs relative to the number of qualified job seekers, a large informal sector is evidence of inefficiency and the need for structural reforms (Taubman and Wachter, 1986). Alternatively, as in the United States and Europe, many workers in developing countries may choose to start small businesses. Indeed the incentives to become an entrepreneur may be even greater in developing countries - rigid regulations may reduce the attractiveness of formal wage employment, and the typically low levels of labor productivity may reduce the opportunity cost of being self-employed. Thus the relatively large share of self-employed seen in many developing countries may reflect an efficient allocation of labor (Maloney, 2000).

The traditional view of a segmented, dualistic labor market further suggests that the selfemployed will earn substantially less than those in formal salaried jobs. However, there is growing evidence that the self-employed in developing countries earn competitive incomes (Vijverberg 1986, Marcouillier, Ruiz de Castilla and Woodruff, 1997), while in developed countries, several studies have shown that the decision to become selfemployed is driven by a positive expected earnings differential between salaried and selfemployment (Rees and Shah, 1986, Evans and Leighton, 1989, and Dolton and Makepeace,1990). $^{2} \quad$ Less tangible factors may also make self-employment more desirable, such as greater flexibility, independence, entrepreneurial achievement, job satisfaction or an appetite for risk. Blanchflower and Oswald (1991), Taylor (1996) and Robson and Wren (1999) find that in the United Kingdom the independence offered by self-employment is a key attraction for individuals moving into the sector, and that the

\footnotetext{
${ }^{2}$ Many studies, in developed and developing countries, find that the distribution of earnings from selfemployment is bi-modal. In these studies it is often shown that using the mean earnings rather than median earnings results in self-employed earnings surpassing earnings in the formal sector. This is due to the
} 
self-employed receive greater returns to entrepreneurial talent. Blau (1987) draws similar conclusions from time series analysis of self-employment in the United States. In developing countries, Blau (1985) finds that the self-employed in Malaysia are endowed with greater managerial ability, while conducting an analysis of labor movement in Peru from 1985 to 1990, Yamada (1996) finds that only successful entrepreneurs remain in the informal sector.

The two characterizations of the labor market also lead to very different predictions of how the share of workers in wage and self-employment will change over the economic cycle. The dualistic model, in which formal salaried jobs are rationed, predicts that the share of self-employed will increase during recessions. High levels of unemployment result in fewer offers of salaried employment, and thus many individuals will prefer selfemployment to spending long periods inactive or searching for work. In this model selfemployment acts as a free-entry, employment "safety net" for the labor market. The dualistic view would, thus, predict counter-cyclical movement in the rate of selfemployment.

The alternative view suggests a "pull” of aspiring entrepreneurs into self-employment when unemployment is low and offers of salaried employment are abundant. In good times, individuals may choose to become self-employed knowing that if their venture fails, an offer of formal salaried employment will not be hard to find. Workers considering self-employment wait for a favorable business climate to leave a protected salaried job (Taylor, 1996). This is to say that in good economic times when aggregate demand is high and businesses are more likely to flourish, there is always a wageemployment safety net that lowers the risks of becoming an entrepreneur. Accordingly, self-employment would show a pro-cyclical pattern - the size of the sector would increase with growth and lower levels of unemployment, and shrink during recessions.

Taylor (1996) shows that the probability of choosing self-employment in the United Kingdom increases as the number of unemployed falls. Robson and Wren (1999) also find that self-employment in the UK increases when buoyant labor market conditions

higher variance in self-employment earnings, were earnings are derived from a wider range of activities, 
provide a cushion against failure. In developing countries, Maloney (1998a \& 1998b) presents evidence of pro-cyclical movement into self-employment in Mexico, Arango and Maloney (2000) find that the share of self-employed in Argentina increases as economic conditions improve, while Fiess, Maloney and Shankar (2000) show similar increases in the share of self-employed in Colombia, Brazil and Chile during periods of expansion. Furthermore, contrary to the dualistic characterization of self-employment as a free-entry sector, Aroca and Maloney (1999) find that younger workers who aspire to entrepreneurship are often barred from starting their own business by credit constraints, and remain in the formal sector until they have accumulated sufficient capital to start their own businesses.

As discussed above, there are several plausible arguments to explain why individuals would prefer self-employment over formal salaried employment. However, most empirical analysis finds significant differences between the self-employed and those in unregulated wage employment. Why would individuals prefer to work in informal salaried jobs? In this segment of the informal economy, workers would presumably be exposed to all the same risks as the self-employed, but without the compensation of greater independence or higher earnings. In a labor market with downwardly flexible wages the cost of mandated non-wage benefits are likely to be partially passed on to employees in the form of reduced wages. Should the value of non-wage benefits to the worker fall below the perceived tax, even risk averse workers with no significant entrepreneurial aspirations may prefer to move into the informal sector and be compensated entirely in cash. Torche and Wagner (1997) show that mandated benefits levy an implicit tax, especially on younger workers, even when contributions are closely tied to the benefits they receive. In developing countries where there is less capacity to enforce labor regulations, the relatively large sector of small firms and diversity of unregulated employment opportunities allow workers to avoid mandated benefits and choose how they are compensated (Maloney, 2000).

from low skilled services labor to providing technical experitise, (Cunningham \& Maloney, 2001) 
Workers in informal salaried jobs are often found to earn the lowest wages in the economy. ${ }^{3}$ However, while they earn significantly less, this is not conclusive evidence that these workers are rationed out of better jobs. Informal salaried employment may serve as a training area for younger workers just leaving study and seeking experience, as well as a conduit to either self-employment or formal wage employment. To the extent that workers in this sector of the informal economy are receiving job training for later employment, lower wages may reflect the cost of training to the informal employer. Hemmer and Mannel, 1989, claim that in many countries informal enterprises train more apprentices and workers than formal education and public job-training schemes together, and that informal work experience constitutes continued schooling. The relative youth of informal salaried workers and the higher rates of turnover in informal wage jobs (relative to formal salaried employment and self-employment), provide preliminary evidence of an apprenticeship mechanism at work in many developing countries. Further, informal wage employees are often related to the owners of the small businesses where they work, and may receive compensation in kind. Thus while this group of workers best fits the traditional characterization of informal employment as the low-paying, residual half of a segmented, dualistic labor market, that informal salaried workers earn less does not necessarily imply that they are worse off in terms of total welfare (Maloney, 2001).

\section{Analytical Approach and Hypotheses}

The dualistic, segmented characterization of labor markets in developing countries, suggests a hierarchy of jobs. As discussed in the previous section, according to this characterization "better" formal sector jobs are not allocated purely by market forces. Distortions introduced by government regulation or strong labor unions, accord significantly different opportunities and rewards to otherwise comparable groups of workers, and earnings levels in the informal sector are lower than in the formal sector even after taking ability into account (Taubman and Wachter, 1986). The alternative characterization posits that individuals seek and find employment in the sector where their abilities and attributes will be best rewarded, that the informal sector is a dynamic

\footnotetext{
${ }^{3}$ In Mexico (Maloney, 1998a), Bolivia, (Pradhan, 1995), and in Peru (Yamada, 1996)
} 
outgrowth of the entrepreneurial sector, whose workers largely select informal employment for the many non-wage benefits they derive from it.

Research on labor market segmentation and sector choice typically focuses on earnings differentials between informal (self and wage employment) and formal employment (Rosenzweig, 1988, Pradhan, 1995, Vijverberg 1986, Marcouillier, et al, 1997). However, the traditional approach that relies solely on earnings differentials - even controlling for sample selection bias - cannot prove or disprove either characterization of the labor market discussed in the previous section (Maloney, 1998a, and 2000). Wage differentials fail to capture the value of unmeasured characteristics of different kinds of work, such as non-wage benefits, compensation for risk, independence, in-kind payments, or implicit training costs. Maloney (2000) stresses that the magnitude of the distortion-free differential cannot be known beforehand, and thus, that researchers have no benchmark against which to compare segmentation. Just as the premium for entering formal salaried work or even self-employment does not imply that either sector is superior, or that workers queue for jobs in the higher paying sector, the discount on earnings in informal employment cannot be taken as conclusive evidence that the sector is inferior.

For these reasons (and concern for the quality of the available data, discussed in the next section) I follow Yamada (1996), Maloney (1998a), and Aroca and Maloney (1999) in analyzing workers' movements across sectors, and in and out of the labor market. To examine sector choice in Chile, I model three employment types: a "formal sector" of contract-wage employment; and an "informal sector" consisting of non-contract wage employment, and self-employment. ${ }^{4}$ I estimate the following sector choice equation for workers switching in and out of employment, and between the sectors.

\footnotetext{
4 From the discussion in the previous section, and as shown empirically in Yamada (1996) and Maloney (1998a), it is not sufficient to simply lump non-contracted wage employees with the self-employed in a single "informal-sector" category. While the probability of successfully evading the mandate to save in Chilean pension system is higher if employees simply collude with employers and declare their income as self-employed (Chamorro, 1992, Macias \& Tarzijan, 1994), F tests show that the two groups of workers are (statistically) significantly different with respect to several variables, notably their age, education and household structure.
} 
$\operatorname{Prob}\left(\ell_{i}^{t} \mid \ell_{i}^{t-1}\right)=\alpha_{i j}+\beta_{j} \mathrm{X}_{i j}+\eta_{j} E_{i j}+\kappa_{j} K_{i j}+\sigma_{j} S_{i j}+v_{i j}$

where $\ell$ is a discrete variable that takes the value $j$ to indicate individual $i$ 's labor market outcome in period $t$, conditional on i's sector of employment in $t-1$ (where $\mathrm{j}=0,1,2, \ldots$, $k$, and $k$ is the number of possible outcomes, including all three sectors of employment and unemployment); $E$ is individual $i$ 's stock of human capital; $K$ is his endowment of physical capital, including assets that can be used as collateral to secure a loan (financial capital); $S$ is the individual's endowment of social capital - specifically, family and friends that may increase the likelihood of access to high-return employment opportunities or overcome information asymmetries in the labor market; $\mathrm{X}$ is a vector of variables controlling for other individual and household characteristics that influence sector choice; $\beta_{j}, \eta_{j}, \kappa_{j}$, and $\sigma_{j}$ are vectors of estimated coefficients on the regressors, and $v$ is an error term.

Is self-employment a free-entry, residual sector where individuals wait for employment opportunities in the formal sector? If there were free-entry into self-employment and the self-employed were simply biding their time queuing with the unemployed and informal employees for scarce formal jobs, one would not expect individuals with their own businesses to be significantly different from the unemployed or from the informally employed. Alternatively, if there were barriers to entry into self-employment - in particular, those presented by poorly functioning capital markets constraining credit to aspiring entrepreneurs - one would expect to find significant differences. All else equal, workers seeking to enter self-employment would have to accumulate a significantly larger endowment of capital with which to cover the costs of starting a business.

Further, if employment without a contract is also more than just a residual sector, and acts as an apprenticeship or job-training institution that leads younger workers to either contracted employment or entrepreneurship, one would expect significant differences between informal workers and the unemployed with respect to their individual characteristics. If informal employment were an apprenticeship mechanism, all else equal, one would expect informal workers (and those entering informal employment) to have a smaller endowment of human capital. Additionally, one would expect 
individuals' endowment of relevant social capital - proxied by the number of selfemployed household members other than the respondent ${ }^{5}$ - to increase the likelihood of employment without a contract over unemployment. This said, if having other household members in self-employment fails to act as a conduit to employment opportunities with greater returns and keeps workers trapped in informal jobs, this “social capital” may be more of a liability than an asset.

The specific set of hypotheses that will be tested in the sections that follow are stated formally below. The subscript $c w$ denotes contract (formal) employment; $n c$, employment without a contract; se, self-employment; and un, denotes unemployment.

\begin{tabular}{|c|c|c|c|}
\hline Ceteris paribus... & Null & Alternative & Implication \\
\hline $\begin{array}{l}\text { 1. Self-employment is a free-entry, } \\
\text { residual sector where workers queue along } \\
\text { with the unemployed and the informally } \\
\text { employed for formal sector jobs. }\end{array}$ & $\begin{array}{l}H_{0}: X_{s e}=X_{j} \\
H_{0}: \mathrm{E}_{s e}=\mathrm{E}_{j} \\
H_{0}: K_{s e}=K_{j} \\
H_{0}: S_{s e}=S_{j} \\
\text { for } j=u n \text { and } j=n c\end{array}$ & $\begin{array}{l}H_{1}: X_{s e} \neq X_{j} \\
H_{1}: \mathrm{E}_{s e} \neq \mathrm{E}_{j} \\
H_{1}: K_{s e}>K_{j} \\
H_{1}: S_{s e} \neq S_{j} \\
\text { for } j=u n \text { and } j=n c\end{array}$ & $\begin{array}{l}\text { Null accepted } \\
\text { implies "yes" }\end{array}$ \\
\hline $\begin{array}{l}\text { 2. There are barriers to entry into self- } \\
\text { employment, and an individual's } \\
\text { endowment of physical capital determines } \\
\text { whether they become self-employed. }\end{array}$ & $\begin{array}{l}H_{0}: \kappa_{j}=0 \\
\text { for all } i \text { whose } \\
\ell^{t} \neq \ell^{t-1}\end{array}$ & $\begin{array}{l}H_{1}: \kappa_{j}>0 \\
\text { for all } i \text { whose } \\
\ell^{t} \neq \ell^{t-1} \text { and } \\
\text { whose } \ell^{t}=s e\end{array}$ & $\begin{array}{l}\text { Null accepted } \\
\text { implies "no" }\end{array}$ \\
\hline $\begin{array}{l}\text { 3. Informal employment is a free-entry, } \\
\text { residual sector where workers queue along } \\
\text { with the unemployed for formal sector } \\
\text { jobs (and/or self-employment). }\end{array}$ & $\begin{array}{l}H_{0}: X_{n c}=X_{u n} \\
H_{0}: \mathrm{E}_{n c}=\mathrm{E}_{u n} \\
H_{0}: K_{n c}=K_{u n} \\
H_{0}: S_{n c}=S_{u n}\end{array}$ & $\begin{array}{l}H_{1}: X_{n c} \neq X_{u n} \\
H_{1}: \mathrm{E}_{n c}<\mathrm{E}_{u n} \\
H_{1}: K_{n c} \neq K_{u n} \\
H_{1}: S_{n c}>S_{u n}\end{array}$ & $\begin{array}{l}\text { Null accepted } \\
\text { implies "yes" }\end{array}$ \\
\hline $\begin{array}{l}\text { 4. Informal employment a form of } \\
\text { apprenticeship, and an individual's }\end{array}$ & $H_{0}: \sigma_{j}=0$ & $H_{1}: \sigma_{j}>0$ & $\begin{array}{l}\text { Null accepted } \\
\text { implies " } n o \text { " }\end{array}$ \\
\hline
\end{tabular}

\footnotetext{
${ }^{5}$ As discussed in the cross-section analysis in Appendix Three, the number of other household members in self-employment significantly increases the probability that the respondent has their own business, and the probability that the respondent is employed without a contract. This may be evidence of entrepreneurial traits shared between family members, as found in the United Kingdom by Taylor (1996) and Blanchflower and Oswald (1998), or that employment without a contract may act as an apprenticeship offered by family members who own their own businesses.
} 
endowment of social capital increases the likelihood of informal employment over unemployment. for all $i$ whose

$\ell^{t} \neq \ell^{t-1}$ for all $i$ whose

$\ell^{t} \neq \ell^{t-1}$ and

whose $\ell^{t}=n c$

\section{The Data}

Is Chile's labor market segmented and dualistic? Gill and Montenegro (1998) find that the labor market in Chile functions efficiently, that workers' endowments of human capital are fairly rewarded, and that earnings from labor contribute to greater income equality. Bravo and Contreras (2001) find that the returns from employment to individuals' investment in human capital in Chile are high. Focusing on the period between 1990 and 1996, Cuesta (2000) finds that high growth in Chile tightened demand for workers in every sector, and further, finds no evidence of constraints on workers' desired labor supply nor of cyclical or structural informal employment. Gill, Haindl, Montenegro and Sapelli (1998) show that from 1987 to 1994 long term unemployment in Chile was practically non-existent. However, studies by Pages and Montenegro (1999), Heckman and Pages (2000), and Edwards and Edwards (2000) find that in terms of job security provisions, Chile's labor market is one of the most rigid in the world, and that these provisions may discriminate against younger workers increasing their number among the unemployed.

Figure 1 plots annual data on economic growth and the composition of the labor force in Chile from 1975 to $2000 .^{6}$ The relative stability in the share of self-employed in the labor force over the past 25 years is intriguing, especially during the years of sustained economic growth after 1984. Also of interest is the fall in both the share of selfemployed and employees in the labor force with the spike in national unemployment during a severe financial crisis in 1982. If the labor market in Chile were dualistic, and self-employment were a free-entry sector or part of the pool of workers seeking formal jobs, one would have expected an increase in their numbers shortly after the sudden downturn in 1982. 
For the empirical analysis in this paper, I employ data from two surveys in Chile - the CASEN $^{7}$ conducted in December 1998, and the PRIESO ${ }^{8}$ gathered in December 1999 and January 2000. The second survey was conducted on a sub-sample of respondents to the CASEN drawn from Greater Metropolitan Santiago. Readers will note that the labor market conditions at the time of each survey were very different. Figure 2 shows the quarterly movement in the rate of unemployment, the shares of wage employment, selfemployment and new job seekers in Grater Metropolitan Santiago from 1997 - 2000. Unemployment in Santiago at the time of the CASEN 1998 stood at $11.4 \%{ }^{9}$ Chile was just entering a recession in the wake of Russia's debt default in August 1998 that initiated a flight of capital from emerging markets, an increase in domestic interest rates, and an economic slowdown in most of Latin America. In the 12 months between the CASEN and the PRIESO the rate of unemployment in Santiago soared to over 15\%. At the time of the second survey unemployment had dropped back to $12 \%$ (only to rise again in the months that followed). Six months after the first survey and prior to the second, in the second quarter of 1999 when unemployment reached its highest level, the share of selfemployed in the labor force rose by 1.13 percentage points, while the share of employees declined by 3.7 percentage points (see Figure 2) - a sector adjustment predicted by the dualistic characterization of the labor market, albeit a relatively small one.

\footnotetext{
${ }^{6}$ Unfortunately the historical data do not allow us to separate informal employees from other salaried workers.

${ }^{7}$ The Encuesta de Caracterizacion Socio-Economica Nacional (CASEN) is an LSMS-type household survey carried out every two years by the Ministry of Planning (MIDEPLAN) through the Department of Economics at the University of Chile. The survey employs multi-stage random sampling with geographical clustering. The survey data are adjusted for non-response, missing income values, and under (or over) reporting of different income categories, against the National Accounts System.

${ }^{8}$ The PRIESO - Encuesta de Prevision de Riesgos Sociales, or Social Risk Management Survey - was designed by the author, and conducted with the help of the Department of Economics at the University of Chile on a sub-sample of respondents to the CASEN 1998 of working age from Greater Metropolitan Santiago. The survey combines features of both household and labor market surveys, to gather previously unavailable data on savings and social insurance. While this paper makes extensive use of the labor module of the PRIESO.

${ }^{9}$ To avoid confusion, readers should note that the data graphed in Figures 1 and 2, are official statistics published by the Instituto Nacional de Estadisticas and the University of Chile, respectively, and that there are significant differences between these and the rates of unemployment among the sample of working age men in Santiago, surveyed in the CASEN and the PRIESO, shown in Table 1.
} 
In December 1998, among male respondents to the CASEN of working age (between 14 and 65) in Santiago, 39.6\% where in contract employment, $11.4 \%$ were employed as salaried workers without a contract, and $17.2 \%$ were self-employed (Table 1). The remainder were either unemployed or inactive. Among working-age male respondents to the PRIESO, 42.4\% where employed with a contract, $11.7 \%$ were employed without a contract, and $19.5 \%$ were self-employed. A smaller share of male respondents was inactive during the later survey, and a larger share were searching for employment. ${ }^{10}$

A casual comparison of the reported average hourly earnings in each sector in December 1998 and December 1999/January 2000 (presented separately for men and women by their level of educational attainment in Table 2) provides some valuable initial insights. In 1998 the self-employed in every category reported significantly (1\% level) higher earnings than their counterparts in contract employment. This pattern is repeated in the earnings data from 1999/January 2000.

Readers will note that the earnings data for the self-employed in the PRIESO in Table 3 is divided into "unadjusted" and "adjusted" earnings to take account of the Chilean Government's correction for underreporting of incomes. For the 1998 wave of the CASEN survey, this correction - minor for salaried employees - involves multiplying the reported earnings of all self-employed by $1.955 .{ }^{11}$ I have applied the same adjustment factor to earnings reported in the PRIESO. ${ }^{12}$ While the effect of the adjustment on the

\footnotetext{
${ }^{10}$ If each share is calculated omitting inactive workers, the rates of unemployment and employment in each sector closely match the aggregate rates shown in Figure 2.

${ }^{11}$ The best available description of this adjustment in English is provided in Litchfield, (2001), and the original in Spanish in CEPAL, (1995). To correct for underreporting of different income categories, the Economic Commission for Latin America and the Caribbean (CEPAL) uses aggregate income flows in the Household Incomes and Expenditures Accounts of the National Accounts System of the Central Bank of Chile. The information in the original Central Bank accounts is converted into the income concepts surveyed in the CASEN. Totals by specific income category from each source are compared, and the proportional differences for each income category between the two sources are imputed uniformly to each income recipient in the CASEN. The underlying assumption is that miss-reporting differs fundamentally across income categories (income from a rental property, versus earned income, or earnings in the different sectors of employment), rather than income levels. Incomes reported by wage employed workers are adjusted by 1.004 , pension benefits by 1.347 , income from rental property by 1.069 , and imputed rent (what the homeowner says his property would be worth if rented) by 0.439 .

${ }^{12}$ Although the two surveys interview the same sample, and the labor module in the PRIESO is designed to be compatible with that of the CASEN, it is not strictly methodologically correct to apply the CEPAL
} 
significance of the positive earnings differential between self and contract employment is dramatic, the earnings of the self-employed without the adjustment are still greater for every category of educational attainment (for men), and even significantly greater among respondents who only completed primary education. However, the adjustment changes the signs of the earnings differentials between women in self-employment and contract employment in the categories with the lowest and the highest educational attainment.

The apparent premium on self-employment remains even after earnings are corrected for sample selection bias (see Table 4) with the two-step procedure proposed by Heckman (1979) and Lee (1983) (see Appendix Three). Using the two-step procedure, I identify positive sample selection into self-employment and employment without a contract in 1998. As discussed in Appendix Three, these results would seem to negate the dualistic, segmented characterization of the labor market in Chile. The positive selection into selfemployment might reflect any number of unobservable traits, such as flexibility, motivation, entrepreneurial ability, greater tolerance of risk, and/or greater desire for independence. Similarly, positive selection into informal wage employment may be evidence of an apprenticeship mechanism at work (motivating the inclusion of the relevant "social capital" variable discussed in the previous section). However, the results of the Heckman-Lee procedure reported in Appendix Three are not robust to even small changes in the sample. Nor do the results hold when the procedure is conducted on the same sample of workers from one year to the next.

There are further problems with relying on the earnings data alone. While the data show a significant premium in self-employment even prior to the adjustment for underreporting (among men in Table 3), and after correcting for possible sample selection bias (in Table 4), they may suffer from serious and potentially systematic (i.e. bias-causing) measurement error. The earnings question in the CASEN - and the same question

adjustments to the PRIESO earnings data. First, the adjustment factor is calculated using national accounts data, and the PRIESO is only representative of Greater Metropolitan Santiago. Second, the adjustment factor was calculated using reported earnings and national accounts data from the same year. I have applied an adjustment factor calculated in 1998 to earnings data reported in 1999. However, regional accounts are not separately kept in Chile, and the CEPAL adjustment factor for earnings from selfemployment has varied only slightly in the last three waves of the CASEN (over the last 6 years). Thus for lack of an adjustment factor for 1999, the 1998 adjustment is the best option. 
repeated in the PRIESO - asked respondents for their "liquid" or take-home income in the last month. However, self-employed respondents are not asked about the capital costs of their businesses, wages paid to employees, or other costs of operation. Nor are these costs among the items respondents are asked to deduct from what they report. ${ }^{13}$ Thus, the “earnings” reported by the self-employed may still include their business costs, leaving researchers no way to distinguish profit from revenue. This could explain the premium on self-employment in Chile, even before the data are adjusted for under-reporting. ${ }^{14}$ Further, since the earnings of the self-employed include a return to physical capital, as well as labor and human capital, the data may not be comparable across sectors. The designers of the CASEN survey are confident that the phrasing of the earnings question elicits data that are comparable across sectors of employment. However, since the phrasing of the question is notably biased toward wage and salaried employment, and no follow up questions are asked, researchers cannot be certain.

Out of concern for the instability of the results of correcting for sample selection bias in Appendix Three, and the comparability of the data discussed above, this paper places greater emphasis on workers' movements between sectors and on data other than actual earnings. The deepening recession and consequent spike in unemployment between the two surveys offers an excellent natural experiment. Although a casual examination of the data on workers' transitions does not provide conclusive evidence to support either thesis of developing country labor markets, there are some interesting patterns.

Of the 2278 respondents to the PRIESO, 33\% changed their labor market status in the twelve months between the two surveys (see Table 5). Of the 1068 male respondents, 34\% changed their status (see panel (i) of Table 5). Among male respondents who switched, the largest group went into contract employment - a surprising pattern in the

\footnotetext{
${ }^{13}$ The CASEN asks respondents to report "liquid" earnings from their principal occupation in the last month. They are specifically asked to deduct taxes, bonuses and any cash benefits they receive (such as child support allowances) from this amount. The questions is phrased: "En el mes pasado, cual fue su ingreso o remuneración liquida en su ocupación principal? Incluya: los descuentos por prestamos y consumos en casas comerciales. Excluya: Las asignaciones familiares, bonificaciones, gratificaciones, descuentos provisionales y de salud."

${ }^{14}$ I am grateful to Dr. Geeta Kingdon for pointing out the potential danger of not accounting for the operating costs of the self-employed.
} 
context of a recession, and one that would contradict the segmentation hypothesis. The second largest group of switchers went into non-contract employment, and the third largest into self-employment. Of those switching out of self-employment, the largest group became inactive, although among men who switched out of self-employment most entered contract jobs (second to last panel (v)) - again, a pattern that would contradict the segmentation hypothesis, given the levels of unemployment. However, among respondents who left contracted employment, most went into non-contract jobs - a pattern more consistent with a dualistic characterization of the labor market.

\section{Results}

Table 6 lists the variables used in the analysis. These include respondents' individual and household characteristics that proxy for factors influencing labor supply (whether the respondent is head of household, married, their number of younger and older dependent children, and whether the respondent resides in a rural area); ${ }^{15}$ their endowment of human capital (captured by age and years of formal education); their physical capital (proxied by a binary variable COLLAT, equal to one if respondents reported owning their home and/or another residential property in 1990 that could act as collateral for a loan); ${ }^{16}$ and their endowment of relevant social capital (proxied by the continuous variable

\footnotetext{
${ }^{15}$ As an example of how these factors can influence labor supply decisions, heads of household, especially those that are married and who have a greater number of dependent children, may be more likely to take up a job in an "inferior" sector out of desperation should they loose formal employment. Further, the employment options of individuals living in rural areas may be relatively constrained. There is a potential problem of reverse causality with some of these control variables - that is, individuals with higher paying jobs in the formal sector can afford to get married or have more children, etc.. However, since this analysis focuses primarily on transitions between sectors in a twelve month period, I have chosen to leave the variables in the model. Estimations without the controls do not lead to significantly different results from those reported in this section.

${ }^{16}$ In testing for sample selection into self-employment, as discussed in Appendix Three, I used the COLLAT variable in the Heckman-Lee procedure on PRIESO respondents. While the coefficient on COLLAT was strongly significant (1\%) for selection into self-employment, I was still unable to replicate the positive, significant coefficient on $\lambda_{\text {se }}$ found in the two-step procedure on 1998 data.
} 
NOTHSEL - the number of household members other than the respondent who declare themselves as self-employed). ${ }^{17}$

Table 7 shows the mean values of four variables of particular interest, AGE, YEDU, COLLAT $^{18}$ and NOTHSEL, for each sub sample of respondents: workers with a contract in December 1998 who stayed in contract employment in December 1999; those that left or lost their jobs and took up employment without a contract; those who went into selfemployment; who were still searching for a job; and those who left the labor market altogether. The mean values of each of the variables are shown for analogous subsamples of respondents who were employed without a contract, self-employed, unemployed and inactive in December 1998. For the sake of brevity, I only report the results of tests for significant differences between certain sub-samples.

The results of two-tailed tests for significant differences in the means between the various groups of interest are very revealing. Although workers with a contract are significantly (5\% level) older than those without a contract, and younger (1\% level) than the selfemployed, they are not significantly more educated than workers in either branch of the informal sector. Workers who left (or lost) a formal job and who became self-employed, while significantly ( $10 \%$ level) younger, are significantly (5\% level) more educated, and as a group hold significantly (1\% level) more collateral than workers who remained in formal employment. There is no significant difference between workers who left or lost formal jobs to take up employment without a contract and those that stayed in the formal sector, other than as a group those that remained formally employed held significantly (1\% level) more collateral. Respondents with a formal job are significantly (1\% level) older and significantly (10\% level) more educated than the unemployed. However, while those that left the formal sector and were still searching for a job are significantly (1\%

\footnotetext{
${ }^{17}$ Of the 4,637 self-employed respondents to the CASEN 1998 in Santiago, 66\% were the only selfemployed in their household. The remainder reported as many as five other household members with their own businesses. Of the 11,808 contract workers in the same sample, $82 \%$ had no other household members who where self-employed, and the rest reported up to four members with their own businesses. Over $76 \%$ of the 4071 workers without a contract in Santiago had no self-employed household members, and the remainder reported as many as four. The number of other household members with their own business was similar among respondents from the three sectors in the PRIESO.
} 
level) younger than those who held on to formal jobs, there is no significant difference in the education of the two groups.

Significant differences between the two branches of the informal sector are also apparent from the mean data in Table 7. Self-employed respondents are significantly (1\% level) older and more educated ( $5 \%$ level) than informal employees, and are significantly ( $1 \%$ level) more likely to hold collateral. Similarly, workers who left the formal sector for self-employment are significantly (1\% level) more educated than those who took up jobs without a contract. While there is no significant difference in the ages of the two groups, the former hold significantly ( $1 \%$ level) more collateral, and have a significantly ( $10 \%$ level) greater number of fellow self-employed in their households. Further, there are differences between the self-employed and the unemployed. The self-employed are significantly ( $1 \%$ level) older, more educated ( $5 \%$ level), and more likely ( $1 \%$ level) to hold collateral than the unemployed. Although not shown in Table 7, the self-employed are significantly ( $1 \%$ level) more likely to be heads of household, and more likely ( $1 \%$ level) to be married than respondents searching for a job.

The are revealing differences between respondents who moved into formal employment from another sector and those that stayed. Former entrepreneurs who moved into a contract job, while significantly (1\%) younger, have significantly (10\% level) more education, hold the same amount of collateral, but have significantly (1\% level) fewer other household members in self-employment than those who remained self-employed. There is no significant difference in age and education between workers without contracts who moved into the formal sector and those that remained in the informal sector. However, workers that remained informal as a group held significantly (10\% level) more collateral. Job seekers who found a formal job were significantly (5\% level) younger than those that continued to search, but otherwise there were no significant differences between the groups.

There is greater similarity between unemployment and informal employment. There are no significant differences between workers without a contract and job seekers with

\footnotetext{
${ }^{18}$ As a binary variable, the mean value of COLLAT for each sub-sample is the percentage of that sample
} 
respect to most of the variables in the model, with only two exceptions. Informal employees are significantly (10\% level) more likely to be heads of household, and to have a significantly (1\% level) greater number of children. These particular differences conflict with the characterization of informal employees as young apprentices, and suggest that job-search in Chile may be a luxury that respondents supporting large numbers of dependents cannot afford. To underscore this interpretation, there is no significant difference in age and education between workers who remained informally employed and those that "graduated" onto employment with a contract or into selfemployment (although those that started their own businesses are significantly (5\% level) older than those that entered the formal sector).

Table 8 (extending over two pages) shows the results of a single multinomial logit estimated on the entire sample of active male respondents interviewed in the PRIESO, where the dependent variable is the respondents' sector of employment or unemployment in December 1999-January 2000, and the omitted reference category is contract employment. $^{19}$ All of the variables in the model were interacted with dummies to control for respondents' sector of employment, unemployment, or inactivity in $1998 .^{20}$ The coefficients estimated in the multinomial logit are relative marginal probabilities and can be interpreted only with reference to the omitted category - employment with a contract in 1999/2000. Thus, I perform a series of F tests for significant differences between the estimated coefficients on the variables of particular interest (AGE, AGE ${ }^{2}, \mathrm{YEDU}$, COLLAT and NOTHSEL) to better interpret the results of the model.

The pattern of transitions between the two surveys is obviously more complex than the dualistic characterization of the labor market would predict. Few of the estimated

with collateral in 1990.

${ }^{19}$ I ran a single regression (instead of separate regressions for each sector), in order to use the smaller sample size in the PRIESO more efficiently. Inactive respondents were excluded from the regression. As in the analysis of the CASEN sample in Appendix Three, workers who declared themselves inactive in the PRIESO were found to be significantly different from those still searching for a job. Further, there was an insufficient number of workers that left the labor market (to become inactive) to allow parameters to be estimated efficiently. Workers who were inactive in the CASEN 1998 and entered the labor market prior to the PRIESO are included.

20 The regressors are sorted in the rows of Table 8 according to respondents' sectors of origin. The columns of Table 8 are respondents' destination sector. 
coefficients on the variables controlling for individual and household characteristics were significant to workers' switching patterns. Relative to workers who were formally hired at the time of the PRIESO, those who left contract jobs and were still searching for employment were significantly (10\% level) less likely to be married. Those that took up self-employment, on the other hand, were more likely to be married and to live in rural areas. $^{21}$ Workers without a contract in December 1998 who remained informally employed came from households with a significantly (5\% level) greater number of children between the ages of 10 and 13 .

Among respondents who left self-employment, those still searching for a job were significantly (1\% level) more likely to be heads of household than their counterparts who found formal employment. ${ }^{22}$ Former entrepreneurs who took up jobs without a contract were significantly ( $10 \%$ level) less likely than those with contract jobs to be married. Little can be said about the individual and household characteristics of respondents moving out of unemployment or into the labor market, except that the unemployed who started their own businesses came from households with a significantly ( $5 \%$ level) greater number of younger children than those that found a contract job.

Respondents' endowment of human capital, proxied in the model by age and years of education, was not as significant a determinant of movement between the sectors as the other variables of interest. Neither respondents' age nor their years of education significantly increased the likelihood of their finding formal jobs over employment in either branch of the informal sector. However, compared to workers in formal employment (with a contract) in December 1999, those who left or lost a contract job and were less educated were significantly ( $10 \%$ level) more likely to still be searching for employment. Turning to the results of the F-tests, a greater endowment of education significantly (5\% level) increased the likelihood that workers leaving the formal sector would start their own business rather than find themselves unemployed. Although there

\footnotetext{
${ }^{21}$ These results are not surprising given that the self-employed are relatively older, and that a switch to agricultural self-employment is more likely in rural areas.

${ }^{22}$ However, the size of the estimated coefficient, indicates that only a few observations may be driving this result.
} 
was no significant difference in the coefficients on the education variable between former contract workers who where searching for a job and those employed informally (without a contract) in December 1999, older workers were significantly (10\% level) more likely to have found employment in the informal sector while younger workers who were more likely to still be searching.

As shown in the table of mean values, workers with a contract who left the formal sector to start their own businesses were significantly ( $10 \%$ level) older, and had significantly (at 5\%) higher education levels than those who stayed. However, although the mean age and level of education of respondents who left contract jobs for self-employment is significantly greater than that of those who stayed in the formal sector, F tests failed to find any significant difference in the estimated coefficients on age and education between the two groups.

The self-employed in December 1998 who continued to run their own businesses a year later, were significantly ( $1 \%$ level) more likely to be older than those who left the sector for formal jobs. Further, there was no significant difference in the level of education between those that continued to run their own businesses and the self-employed who left for employment in the formal sector (or for jobs without a contract). However, compared with respondents who left self-employment to take up jobs with a contract, those with less education were significantly ( $1 \%$ level) more likely to still be searching for jobs. These workers were also significantly ( $1 \%$ level) less educated than respondents who left self-employment and took up informal employment or those who remained selfemployed.

Age and education seem to have been even less important to the movement of workers out of informal employment. Although workers without a contract in December 1998 who were searching for a job a year later, were significantly ( $10 \%$ level) older than those that remained informally employed, the estimated coefficient on education is not statistically significant to the movement of informal workers into any other sector. Follow-up $\mathrm{F}$ tests confirm that there is no significant difference in the estimated coefficient on education between workers who were still searching and those who 
remained in non-contracted jobs. Nor were age and education significant determinants of whether workers remained informally employed of opened their own businesses. Furthermore, there was no significant difference in the estimated coefficients on either age or education between those that remained informally employed and those who moved out of informal employment for jobs in the formal sector.

In contrast, workers' endowment of physical capital (and access to financial capital), proxied by their holding of collateral, was highly significant to their switching patterns between the sectors. The most striking feature of the transitions out of contract employment is that respondents were sorting between the two branches of the informal sector according to their holdings of collateral. Compared to those who remained in formal employment, workers leaving the formal sector to become self-employed were significantly (5\% level) more likely to have the collateral with which to start a business. In contrast, those who took up employment without a contract were significantly ( $10 \%$ level) less likely to hold collateral. F tests confirm this result. Workers who either left or lost a job in the formal sector to become self-employed were significantly (1\% level) more likely to hold collateral than those that took a job without a contract. This may be evidence of either a considered, strategic move into self-employment, or of workers using their collateral to start a business to cope with involuntary job loss. The latter interpretation is supported by the finding that new entrepreneurs were significantly ( $10 \%$ level) more likely to hold collateral than those who left a contract job but were still searching for employment in 1999.

A collateral endowment (or the lack thereof) was also an important determinant of transitions into and out of the remaining sectors. The estimated coefficient on COLLAT for self-employed workers who took up employment without a contract is negative and highly significant (at 1\% level). Entrepreneurs in 1998 who took up jobs without a contract or who were still searching for employment in 1999 were significantly (1\% level) less likely to hold collateral than those who were still self-employed. These results may be evidence of a cyclical "push" out of self-employment, and indicate that the selfemployed with collateral may have been able to secure credit with which to ride out the adverse business climate brought by the recession. Although $\mathrm{F}$ tests cannot find 
significant differences in the estimated coefficients on COLLAT between those who left self-employment for contract jobs and those who remained in the sector, the difference between former self-employed in contract and non-contract jobs is highly significant. Former entrepreneurs who took a job without a contract had significantly (1\% level) less collateral than those that entered the formal sector. These former entrepreneurs who went into the formal sector may have used their collateral endowment to leverage financing for a more extended job search than those without assets could afford. ${ }^{23}$

There was no significant difference between the coefficients on the collateral variable between the unemployed who took up jobs without a contract, and those still searching. Nor was there a difference between former job seekers who entered informal employment, self-employment, or the formal sector. Similarly, the estimated coefficient on collateral was not significantly different from zero for transition into the labor market, regardless of the sector where formerly inactive respondents became employed.

Respondents' endowment of social capital, proxied in the model by the number of other household members in self-employment, had a significant, if only a minor, effect on their switching patterns. As shown by the estimated coefficients on NOTHSEL in Table 8, compared with the formally employed, the self-employed who continued to run their own business; those who left self-employment and took jobs without a contract; and those who were searching for employment in December of 1999, were significantly (10\% level) more likely to have a greater number of other household members who were selfemployed. While less apparent in the regression results in Table 8, F tests show that respondents that left self-employment and found contract jobs, had significantly (5\% level) fewer self-employed household members than those that continued to run their own business. Those who left self-employment and took up a job without a contract had a significantly (10\% level) greater number of household members who were self-employed than those that found formal jobs.

\footnotetext{
${ }^{23}$ I am confident that the collateral variable is capturing more than just the effect of greater earnings capacity. While I have refrained from including actual and predicted earnings data in the model, for the reasons discussed in Section IV, the signs and significance of the estimated coefficients on the collateral variable are very similar even when actual and predicted earnings are included as control variables.
} 
However, there is little evidence of an apprenticeship mechanism at work. The significance of other self-employed household members to respondents' transitions may simply be evidence of entrepreneurs coping with an adverse economic climate by relying on family members to find work while they recover from a shock. There is no evidence that the number of self-employed in the household significantly increases the likelihood of self-employment or employment without a contract over unemployment among job seekers, and those entering the job market for the first time.

\section{Conclusion}

Are workers in developing countries employed in the informal sector by chance or by choice? The answer to this question is critical to the analysis of individual income security in retirement in countries where one sector is mandated to contribute to social insurance and others are not. In this paper I have focused on the labor market in Chile where the government enforces a partial mandate to participate in the social security system. Employees are mandated to contribute to individual retirement accounts, while the self-employed are left to choose whether to contribute. To the extent that they can evade labor market regulations, salaried workers without a contract can also avoid contributing.

If contracted jobs are not rationed, and individuals choose employment in the informal sector, policy makers may be justified in expecting the self-employed and informal wage employees to take greater responsibility for financing their retirement, and should turn their attention to other detriments to securing an adequate income for old age. However, if workers in the informal sector are queuing along with the unemployed for formal jobs, and the only reason they fail to save is that they are not working in - or have been pushed out of - the sector mandated to save, policymakers cannot afford to be complacent, and should work toward removing obstacles to formal employment.

The results reported in the previous section can be summarized as answers to the hypotheses presented formally in Section III. Is self-employment a free-entry, residual sector where workers queue along with the unemployed and the informally employed for 
scarce formal sector jobs? A casual analysis of the data on labor market transitions in Chile shows little evidence that jobs in the formal sector are especially scarce. The largest share of workers who left either branch of the informal sector, as well as the largest group of job seekers who found employment, took up formal sector jobs. Furthermore, there is no evidence that self-employment is part of the residual sector of a dualistic labor market. The self-employed in Chile are clearly distinct from both the unemployed and workers employed without a contract. The self-employed are significantly older, more educated, more likely to be heads of household, and more likely to hold collateral than either the informally employed or the unemployed.

There are significant barriers to entry into self-employment. An endowment of physical capital increases the likelihood of becoming an entrepreneur over employment in any other sector. Workers who left or lost jobs in the formal sector, sorted between selfemployment and informal employment depending on whether they held collateral. These workers may have been using their endowment of collateral to cope with job losses from the negative shock to aggregate demand during the recession in Chile. Just as with workers leaving contract jobs, those who left self-employment for non-contract jobs were significantly less endowed with collateral than those that continued to run their own businesses. These former entrepreneurs may not have had access to the extra capital necessary to weather losses from the recession.

Is informal employment a free-entry, residual sector where workers queue along with the unemployed for formal sector jobs? Unlike self-employment, employment without a contract does exhibit the characteristics of the free-entry, residual, employment safety-net depicted in the dualistic literature. Workers without a contract are almost indistinguishable from the unemployed. However, those employed without a contract are more likely to be heads of household and to have a greater number of dependents to support. Further, despite the positive self-selection into informal employment found in Appendix Three, individuals' endowment of social capital - the number of other household members in self-employment - has no significant effect on the likelihood they are employed informally rather than unemployed. 
To summarize, in Chile, I find evidence of both an entrepreneurial "pull" into selfemployment as well as a cyclical "push" into and out of the sector due to adverse macroeconomic conditions. However, there is little evidence indicating that selfemployment is the residual sector of a dualistic labor market. Entrepreneurs are not queuing for jobs in the formal sector, and can be "pushed" out of self-employment, just as others are pushed out of formal employment during economic downturns. In contrast, employment without a contract does exhibit many of the features of a free-entry, employment safety net. Workers without a contract are virtually indistinguishable from those searching for a job, and are likely to have taken up informal employment out of greater necessity to support dependants.

The results presented in this paper indicate that policy makers concerned for limited coverage of the reformed social insurance system in Chile, should worry less about where workers are employed. Since there is little evidence that contract jobs are rationed, and the results presented suggest that individuals choose self-employment, interventions to ensure adequate income in old age might be better concentrated on maintaining sound macroeconomic management, spreading awareness of income needs in retirement and the importance of savings, as well as on correcting failures that constrain capital and insurance markets from offering households a greater array of savings, investment and insurance instruments. This said, the evidence presented also suggests there may be cause for concern for workers employed without a contract. This may indicate a need not only to increase governments' capacity to enforce the mandate to participate, but also to lower the transactions and compliance costs of affiliating workers and maintaining their contributions up to date. Further, the apparent impact of economic downturns on workers in the formal and informal sectors alike, suggest that special provisions may have to be made for those who stop contributing to the pension system due to job-loss during crises, to shorten periods without cover against the more immediate risks to household income from disability and sudden death. 


\section{REFERENCES}

AROCA Gonzalez, Patricio and William F. Maloney (1999), “Logit Analysis in a Rotating Panel Context and an Application of Self-employment Decisions” Policy Research Working Paper No. 2069, World Bank, Washington D.C.

BARR, Abigail \& Truman Packard, (2000), "Revealed and Concealed Preferences and Self Insurance: Can we Learn from the Self-employed in Chile” Oxford University, Department of Economics Discussion Paper Series No. 53

(2002) "Revealed Preference and Self-Insurance: Can We Learn from the Self-Employed in Chile?", PRWP No. 2754

BLANCHFLOWER, D. and Andrew J. Oswald (1991), “Self-employment and Mrs. Thatcher's Enterprise Culture”, Center for Economic Performance, Discussion Paper No. 30

(1998), “What Makes an Entrepreneur?” Journal of Labor Economics, 1998, vol. 16, no. 1, pp. 26 $-59$

BLAU, David M., (1985), “Self-employment and Self-Selection in Developing Country Labor Markets”, Southern Economic Journal 51, no. 2, pp. 351-63

(1987) “A Time-Series Analysis of Self-Employment in the United States”, Journal of Political Economy, Vol. 95, pp. 445 - 467

CEPAL (1995), "La Medicion de los Ingresos en la Perspectiva de los Estudios de Pobreza: El caso de la Encuesta CASEN de Chile: 1987 - 1994” CEPAL Working Paper LC/R. 1604, December

CHAMORRO, Claudio, (1992), “La Cobertura del Sistema de Pensiones Chileno”, Pontifica Universidad Catolica de Chile, Instituto de Economia, Santiago

CUESTA, Jose A., (2000), "Social Transfers, the Household, and the Distribution of Incomes in Chile”, Doctoral Thesis, University of Oxford

DOLTON, P. J. and Makepeace, G. H., (1987) “Interpreting Sample Selection Effects”, Economic Letters, Vol. 24, pp. 373 - 79

EVANS, D. and Leighton, L. (1989), “Some Empirical Aspects of Entrepreneurship”, American Economic Review, Vol. 79, pp. 519 - 535

FIELDS, Gary, (1975), "Rural-Urban Migration, Urban Unemployment and Under-employment, and Job Search Activities in LDCs”, Journal of Development Economics, pp. 165-188

(1990) “Labor Market Modeling and the Urban Informal Sector: Theory and Evidence," in OECD, The Informal Sector Revisited.

FIESS, Norbert, William F. Maloney, and Rashmi Shankar, (2000), “The Informal Sector, Wage Rigidities, and Real Exchange Rates.” World Bank, Poverty Reduction and Economic Management Department, Washington, D.C.

GILL, Indermit \& Claudio Montenegro (1998) “Is Chile’s Labor Market Serving the Poor as Well as it Does the Rich?” in Gill \& Montenegro Eds., Re-addressing the Forgotten Reform in Latin America: Quantifying Labor Policy Challenges in Argentina, Brazil and Chile, World Bank

GILL, Indermit, Erik Haindl, Claudio Montenegro \& Claudio Sapelli (1998) "Has Employment in Chile Become More Precarious" in Gill \& Montenegro Eds., Re-addressing the Forgotten Reform in Latin America: Quantifying Labor Policy Challenges in Argentina, Brazil and Chile, World Bank

GILL, Indermit, Truman Packard and Juan Yermo, (2004) Keeping the Promise of Social Security in Latin 
America, with the assistance of Todd Pugatch, Stanford University Press

HARRIS, John. R. and Michael P. Todaro, (1970), "Migration, Unemployment and Development: A Two Sector Analysis” American Economic Review, March, pp. 126 - 142

HECKMAN, J. and C. Pages (2004) Law and Employment, NBER Chicago

HECKMAN, James, (1979), “Sample Selection Bias as a Specification Error” Econometrica, January, pp. $153-161$

HOLZMANN, R., Truman Packard \& Jose Cuesta (2001) "Extending Coverage in Multi Pillar Pension Systems: Constraints and Hypotheses, Preliminary Evidence and Future Research Agenda" in R. Holzmann \& J. Stiglitz, Eds. New Ideas About Old Age Security, The World Bank

KINGDON, Geeta G., (1996), “Private Schooling in India: Size, Nature and Equity Effects”, Development Economics Research Program, Discussion Paper, No. 72, Suntory-Toyota International Center for Economics and Related Disciplines

KNIGHT, F., (1921), Risk, Uncertainty, and Profit, Houghton-Miffin, New York

KREBS, Tom and William F. Maloney (1999), “Quitting and Labor Turnover: Microeconomic Evidence and Macroeconomic Consequences” Policy Research Working Paper No. 2068, World Bank, Washington D.C.

LAFFONT, Jean-Jacques, (1979), Aggregation and Revelation of Preferences, Amsterdam, Oxford, NorthHolland

LEE, Lung-Fei, (1978), “Unionism and Wage Rates: A Simultaneous Equations Model with Qualitative and Limited Dependent Variables” International Economic Review, June, pp. 415 - 434

(1979), "Identification and Estimation of Binary Choice Models with Limited (Censored) Dependent Variables”, Econometrica, July, pp. 977 - 996

(1983) “Generalized Econometric Models with Selectivity,” Econometrica, March

LEVENSON, Alec R. and William F. Maloney, (1998), “The Informal Sector, Firm Dynamics and Institutional Participation” Policy Research Working Paper No. 1988, World Bank, Washington D.C.

LEWIS, W., (1954), “Economic Development with Unlimited Supply of Labor” Manchester School of Economics and Social Studies

LITCHFIELD, Julie, (2001) “Updated Income Distribution and Poverty Measures for Chile: 1987 - 1998” Background Paper No. 1, in World Bank, (2001) "Poverty and Income Distribution in a High Growth Economy: The Case of Chile 1987 - 1998”, Washington, D.C.

MACIAS, Osvaldo \& Jorge Tarzijan (1994), “Origen y Magnitud de la Evasion en el Sistema de Pensiones Chileno Derivado de la Capitalizacion Individual” CEPAL/PNUD Serie Politica Fiscal No. 53, Santiago

MALONEY, W. and Nunez Mendez, J. (2004) "Measuring the Impact of Minimum Wages: Evidence from Latin America." In James Heckman \& Carmen Pages eds. "Law and Employment: Lessons from Latin America and the Caribbean,” U. Chicago Press and NBER

MALONEY, William F. (1998a), "The Structure of the Labor Market in Developing Countries: Time Series Evidence and Competing Views” Policy Research Working Paper No. 1940, World Bank, Washington D.C.

(1998b), “Are Labor Markets in Developing Countries Dualistic?” Policy Research Working Paper No. 1941, World Bank, Washington D.C.

(1999), "Does Informality Imply Segmentation in Urban Labor Markets? Evidence from Sectoral Transitions in Mexico” The World Bank Economic Review, Vol. 13, No. 2, pp. 275 - 302 , 
Washington D.C.

(2000), "Minimum Wages in Latin America: A Note” Poverty Reduction and Economic Management Department, World Bank, Washington, D.C.

(2001), “Informality Revisited” Poverty Reduction and Economic Management Department, World Bank, Washington, D.C.

(2004) “Informality Revisited” World Development 32(7) 1159-1

MARCOUILLER, D.V., Ruiz de Castilla and C. Woodruff (1997) "Formal Measures of the Informal Sector Wage Gap in Mexico, El Salvador, and Peru”, Economic Development and Cultural Change

MESA-LAGO, Carmelo, (2000), "Social Assistance, Pensions and Health Care for the Poor in Latin America and the Caribbean. In Nora Lustig ed. Shielding the Poor: Social Protection in the Developing World. Washington D.C.: The Brookings Institution and the IADB

PACKARD, Truman (2002) "Are there positive incentives from privatizing social security? A panel analysis of pension reform in Latin America." Journal of Pensions Economics and Finance, Vol 1., No. 2

PAGES, Carmen and Claudio Montenegro, (1999) "Job Security and the Age Composition of Employment: Evidence from Chile” Inter-American Development Bank, Washington, DC

PRADHAN, Menno (1995), “Sector Participation Decisions in Labor Supply Models” LSMS Working Paper No. 113, World Bank, Washington D.C.

PRIESO 2000, Encuesta de Prevision de Riesgos Sociales, Santiago, Chile, Social Risk Management Survey, designed by Truman Packard \& Jose Cuesta,

REES, H. and A. Shah, (1986), “An Empirical Analysis of Self-Employment in the UK”, Journal of Applied Econometrics, Vol. 1. pp. 95-108

ROBSON, Martin T. and Colin Wren, (1999), "Marginal and Average Tax Rates and the Incentive for Selfemployment” Southern Journal, 65 (4), pp. 757 - 773

TAYLOR, Mark, P. (1996), “Earnings, Independence or Unemployment: Why Become Self-employed?” Oxford Bulletin of Economics and Statistics, 58, 2, pp. 253 - 265

THOMAS, J., (1996) “The New Economic Model and Labor Markets in Latin America”, in Victor BulmerThomas, ed., The New Economic Model in Latin America and Its Impact on Income Distribution and Poverty, Institute of Latin American Studies, University of London

TORCHE, Aristides \& Gert Wagner (1997), "Prevision Social: Valoracion Individual de un Beneficio Mandatado”, Cuadernos de Economia, No. 103, PUCC.

UUSITALO, Roope, (1999), “Homo Entreprenaurus?” Working Paper No. 205, Government Institute for Economic Research, Helsinki

VIJVERBERG, Wim P. M., (1986), “ Consistent Estimates of the Wage Equation When Individuals Choose among Income-Earning Activities”, Southern Economic Journal, Vol. 52, pp. 1028 - 42, April

WORLD BANK (2001) "Poverty and Income Distribution in a High Growth Economy: The Case of Chile 1987 - 1998” Poverty Reduction and Economic Management Sector Unit, Latin America and the Caribbean Regional Office, Washington, D.C.

(2006) “Equity and Development”, World Development Report, Oxford University Press

(2006b) "Policy Options for Better Old Age Income Security in Chile" Pensions Policy Note in "Chile: Towards Equality of Opportunity" Report No 36583-CL 
YAMADA, G., (1996) "Urban Informal Employment and Self-Employment in Developing Countries: Theory and Evidence”, Economic Development and Cultural Change 44: 289-314. 
Figure 1. Composition of the Labor Force and Related Macroeconomic Indicators in Chile, 1975 - 2000

(Sources: World Bank/SIMA, Instituto Nacional de Estadisticas - INE)

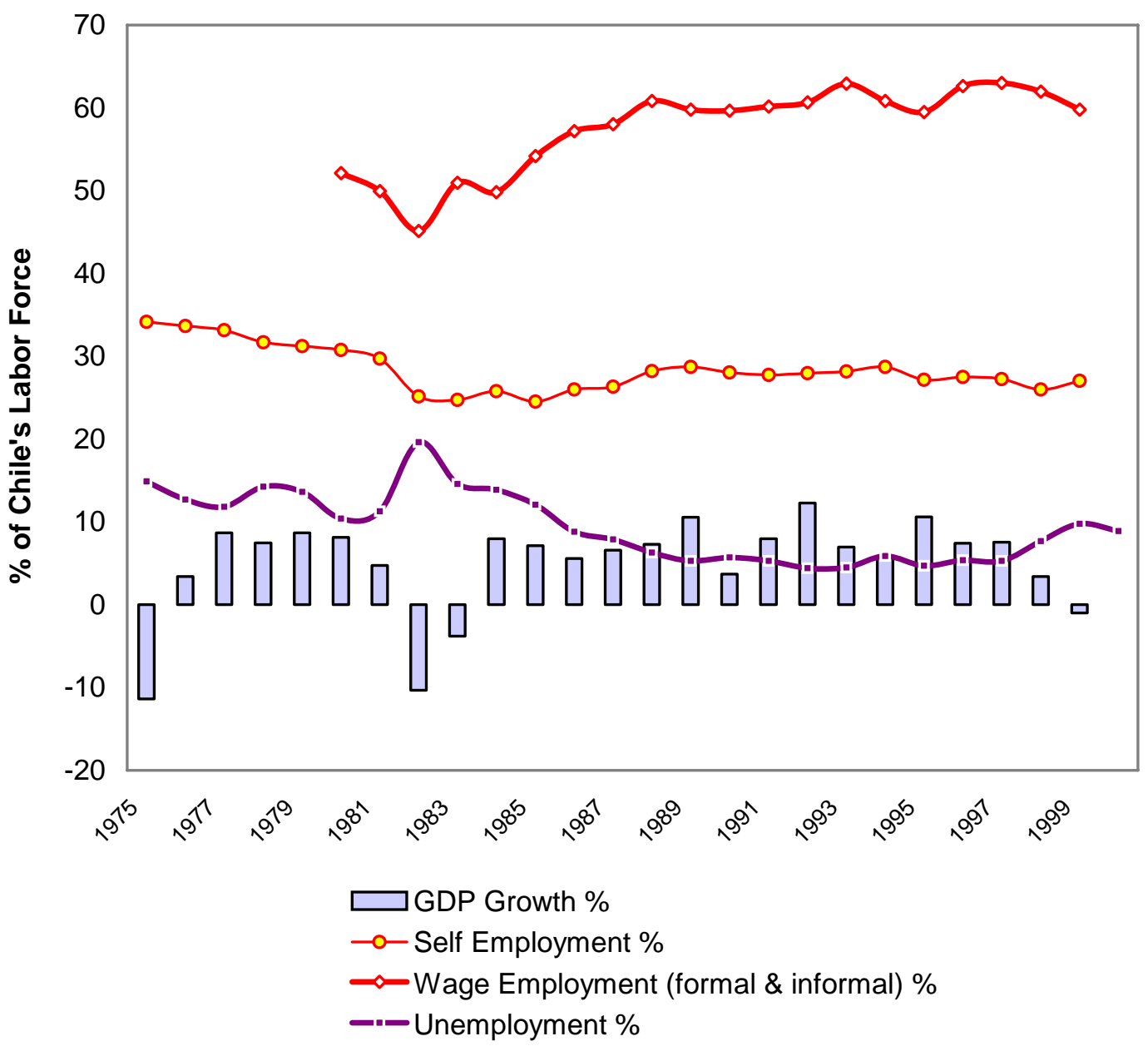


Figure 2. Unemployment and Labor Force Composition, Greater Metropolitan Santiago, $1997-2000$

(Source: Survey Unit, Department of Economics at University of Chile)

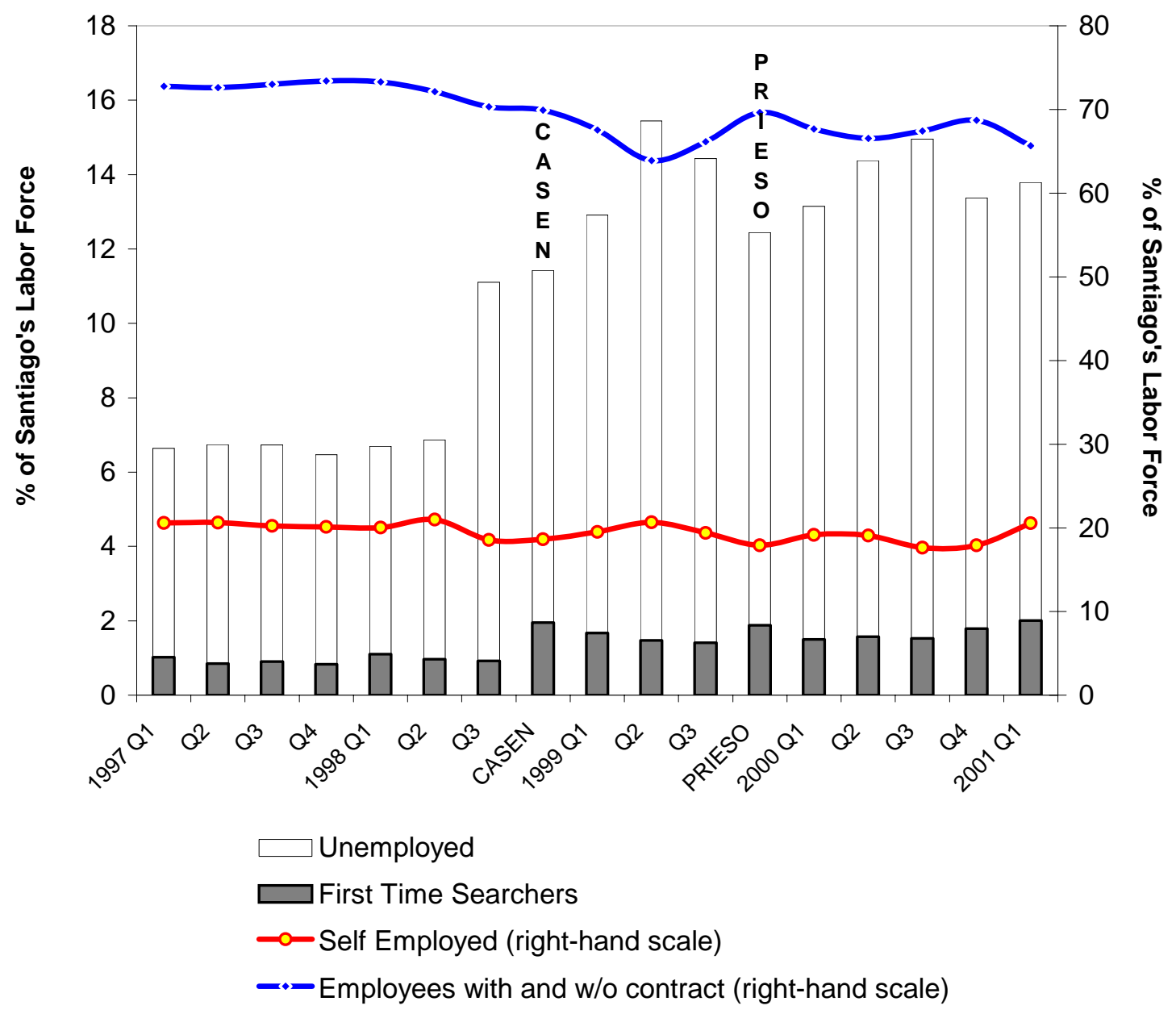




\section{Table 1. Sector Allocation of Santiago's Labor Force, CASEN 1998 \& PRIESO 1999/2000}

\begin{tabular}{lcccc}
\hline \hline & \multicolumn{2}{c}{ December 1998} & \multicolumn{2}{c}{ December 1999/January 2000} \\
\cline { 2 - 5 } & & $\%$ & No. Obs. & $\%$ \\
\cline { 2 - 5 } Inactive & 4699 & & 202 & 18.9 \\
Unemployed & 1304 & 24.8 & 80 & 7.5 \\
Non-Contract Employee & 2161 & 6.9 & 125 & 11.7 \\
Self-employed & 3262 & 11.4 & 208 & 19.5 \\
Contract Employee & 7490 & 17.2 & 453 & 42.4 \\
& & 39.6 & & $\mathbf{1 0 0}$ \\
Total & $\mathbf{1 8 9 1 6}$ & $\mathbf{1 0 0}$ & $\mathbf{1 0 6 8}$ & $\mathbf{1 0 0}$ \\
\hline \hline
\end{tabular}

\section{Table 2. Average Hourly Earnings by Sector and Educational Attainment, and Earnings Differentials, CASEN 1998}

\begin{tabular}{|c|c|c|c|c|c|c|}
\hline & \multicolumn{3}{|c|}{ Hourly Earnings } & \multicolumn{3}{|c|}{ Real Earnings Differentials } \\
\hline & $\begin{array}{c}\text { Contract } \\
\text { worker }(\mathrm{cw})\end{array}$ & $\begin{array}{l}\text { Non-contract } \\
\text { workers (nc) }\end{array}$ & $\begin{array}{c}\text { Self- } \\
\text { employed (se) }\end{array}$ & $\mathrm{cw}-\mathrm{nc}$ & se - cw & se - nc \\
\hline \multicolumn{7}{|l|}{ Men } \\
\hline Some primary & 701.805 & 582.965 & 1599.984 & $118.84 * * *$ & $898.18^{* * *}$ & $1017.02 * * *$ \\
\hline Complete primary & 736.600 & 644.685 & 1723.663 & $91.92 * *$ & $987.06 * * *$ & $1078.98 * * *$ \\
\hline Some secondary & 809.611 & 664.072 & 1889.496 & $145.54 * * *$ & $1079.89 * * *$ & $1225.42 * * *$ \\
\hline Complete secondary & 1026.323 & 871.243 & 3035.858 & $155.10 * * *$ & $2009.54 * * *$ & $2164.61^{* * *}$ \\
\hline Some tertiary & 1651.376 & 1426.951 & 5627.220 & $224.43^{*}$ & $3975.84 * * *$ & $4200.30 * * *$ \\
\hline Completed tertiary & 4099.920 & 3007.210 & 10650.740 & $1092.71 *$ & $6550.82 * * *$ & $7643.53 * * *$ \\
\hline \multicolumn{7}{|l|}{ Women } \\
\hline Some primary & 606.033 & 599.288 & 1618.223 & 6.75 & $1012.19 * * *$ & $1018.94 * * *$ \\
\hline Complete primary & 647.352 & 633.491 & 1442.869 & 13.86 & $795.52 * * *$ & $809.38 * * *$ \\
\hline Some secondary & 658.306 & 651.034 & 1704.425 & 7.27 & $1046.12 * * *$ & $1053.39 * * *$ \\
\hline Complete secondary & 881.573 & 800.801 & 2772.297 & $80.77 * *$ & $1890.72 * * *$ & $1971.50 * * *$ \\
\hline Some tertiary & 1392.310 & 1329.792 & 4177.154 & 62.52 & $2784.84^{* * *}$ & $2847.36^{* * *}$ \\
\hline Completed tertiary & 2727.998 & 3159.127 & 7505.059 & -431.13 & $4777.10^{* * *}$ & $4345.93^{* * *}$ \\
\hline
\end{tabular}

“***” indicates significance at $1 \%$; “**” at $5 \%$; “*” at $10 \%$ 
Table 3. Average Hourly Earnings by Sector and Educational Attainment, and Earnings Differentials, PRIESO 1999/2000

\begin{tabular}{|c|c|c|c|c|c|c|c|c|c|}
\hline & \multicolumn{4}{|c|}{ Hourly Earnings } & \multicolumn{5}{|c|}{ Real Earnings Differentials } \\
\hline & \multirow[t]{2}{*}{$\mathbf{c w}$} & \multirow[t]{2}{*}{ nc } & \multicolumn{2}{|r|}{ se } & \multirow[t]{2}{*}{ cw- nc } & \multirow[t]{2}{*}{ se - cw (1) } & \multirow[t]{2}{*}{ se - cw (2) } & \multirow[t]{2}{*}{ se - nc (1) } & \multirow[t]{2}{*}{ se - nc (2) } \\
\hline & & & Unadjusted & Adjusted & & & & & \\
\hline \multicolumn{10}{|l|}{ Men } \\
\hline Some primary & 716.29 & 551.40 & 720.37 & 1408.32 & $164.89 * * *$ & 4.08 & $692.03 * * *$ & $168.97 * *$ & $856.92 * * *$ \\
\hline Complete primary & 828.64 & 634.62 & 1579.77 & 3088.45 & 194.02 & 751.13* & $2259.81 * *$ & 945.15 & $2453.83 * * *$ \\
\hline Some secondary & 848.92 & 649.48 & 1375.21 & 2688.53 & 199.44 & $526.29 * *$ & $1839.60 * * *$ & $725.73 * * *$ & $2039.05 * * *$ \\
\hline Complete secondary & 1145.26 & 697.55 & 1263.66 & 2470.46 & $447.72 * * *$ & 118.40 & $1325.20^{* * *}$ & $566.12 * * *$ & $1772.92 * * *$ \\
\hline Some terciary & 1611.20 & 592.42 & 1856.46 & 3629.37 & $1018.77 * * *$ & 245.26 & $2018.18^{* * *}$ & $1264.03^{* *}$ & $3036.95 * * *$ \\
\hline Complete terciary & 3904.24 & 2621.71 & 5598.48 & 10945.03 & 1282.53 & $1694.24 * *$ & $7040.79 * * *$ & $2976.77^{*}$ & $8323.32 * *$ \\
\hline \multicolumn{10}{|l|}{ Women } \\
\hline Some primary & 646.91 & 529.53 & 600.59 & 1174.16 & 117.4 & -46.32 & $527.25^{* *}$ & 71.06 & $644.63 * * *$ \\
\hline Complete primary & 532.54 & 448.27 & 548.70 & 1072.71 & 84.3 & 16.2 & $540.20 * * *$ & 100.44 & $624.44 * * *$ \\
\hline Some secondary & 857.26 & 639.12 & 923.07 & 1804.61 & $218.14 *$ & 65.81 & $947.34 * * *$ & 283.95* & $1165.49 * * *$ \\
\hline Complete secondary & 829.61 & 957.65 & 1149.52 & 2247.31 & -128.04 & $319.91 * *$ & $1417.70^{* * *}$ & 191.87 & $1289.66^{* * *}$ \\
\hline Some terciary & 1098.01 & 1100.04 & 1175.80 & 2298.68 & -2.02 & 77.8 & $1200.70^{* *}$ & 75.76 & 1198.66 \\
\hline Complete terciary & 2927.70 & 1351.54 & 2604.55 & 5091.89 & $1576.20^{* *}$ & -323.15 & $2164.20^{* *}$ & 1253.01 & $3740.35^{*}$ \\
\hline
\end{tabular}

(1) Using unadjusted earnings for self-employed

(2) Using adjusted earnings for self-employed 
Table 4. Predicted Hourly Earnings, and Earnings Differentials Corrected for Sample Selection Bias, by Sector and Educational Attainment

(As Discussed in Appendix)

\begin{tabular}{|c|c|c|c|c|c|c|c|}
\hline & \multicolumn{4}{|c|}{ Predicted Hourly Earnings, 1998} & \multicolumn{3}{|c|}{ Predicted Differentials } \\
\hline & \multirow[t]{2}{*}{$\begin{array}{l}\text { Contract worker } \\
\text { (cw) }\end{array}$} & \multirow[t]{2}{*}{$\begin{array}{l}\text { Non contract worker } \\
\text { (nc) }\end{array}$} & \multicolumn{2}{|c|}{$\begin{array}{l}\text { Self-employed } \\
\text { (se) }\end{array}$} & \multicolumn{2}{|c|}{ se - cw } & \multirow[t]{2}{*}{ cw-nc } \\
\hline & & & (i) & (ii) & (i) & (ii) & \\
\hline Some Primary & 547.047 & 297.038 & 1040.693 & 532.003 & 493.646 & -15.045 & 250.010 \\
\hline Complete Primary & 598.893 & 316.438 & 1196.580 & 610.840 & 597.687 & 11.948 & 282.455 \\
\hline Some Secondary & 651.698 & 329.262 & 1363.917 & 696.838 & 712.219 & 45.140 & 322.436 \\
\hline Complete Secondary & 803.453 & 362.859 & 1809.369 & 919.071 & 1005.916 & 115.618 & 440.594 \\
\hline Some Terciary & 1177.938 & 516.830 & 3046.619 & 1549.718 & 1868.681 & 371.780 & 661.108 \\
\hline Complete Terciary & 3055.027 & 981.961 & 7679.537 & 3893.239 & 4624.509 & 838.211 & 2073.067 \\
\hline All Sample & 790.731 & 377.030 & 1704.637 & 868.696 & 913.905 & 77.965 & 413.701 \\
\hline
\end{tabular}

(i) Uses adjusted earnings

(ii) Uses unadjusted earnings 


\section{Table 5. Worker Transitions Between Sectors and In and Out of Employment, December 1998 to December 1999/January 2000}

\begin{tabular}{|c|c|c|c|c|}
\hline \multirow{2}{*}{$\begin{array}{l}\text { Labor Market Status in PRIESO: } \\
\text { i. Of all "Switchers" }\end{array}$} & \multicolumn{2}{|c|}{ All Respondents } & \multicolumn{2}{|c|}{ Male Respondents 14 - 65} \\
\hline & No. Obs. & $\%$ & No. Obs. & $\%$ \\
\hline Inactive & 138 & 18.83 & 23 & 6.32 \\
\hline Unemployed \& Searching & 141 & 19.24 & 67 & 18.41 \\
\hline Non-Contract Wage & 155 & 21.15 & 89 & 24.45 \\
\hline Self-employed & 137 & 18.69 & 79 & 21.7 \\
\hline Contract Wage & 162 & 22.1 & 106 & 29.12 \\
\hline Total & 733 & 100 & 364 & 100 \\
\hline \multicolumn{5}{|c|}{ ii. Those who Entered the Labor Market } \\
\hline Unemployed \& Searching & 67 & 30.73 & 22 & 30.56 \\
\hline Non-Contract Wage & 56 & 25.69 & 22 & 30.56 \\
\hline Self-employed & 52 & 23.85 & 12 & 16.67 \\
\hline Contract Wage & 43 & 19.72 & 16 & 22.22 \\
\hline Total & 218 & 100 & 72 & 100 \\
\hline \multicolumn{5}{|l|}{ iii. Switched out of Unemployment } \\
\hline Inactive & 29 & 28.43 & 4 & 6.9 \\
\hline Non-Contract Wage & 21 & 20.59 & 15 & 25.86 \\
\hline Self-employed & 22 & 21.57 & 17 & 29.31 \\
\hline Contract Wage & 30 & 29.41 & 22 & 37.93 \\
\hline Total & 102 & 100 & 58 & 100 \\
\hline \multicolumn{5}{|c|}{ iv. Switched out of Non-Contract Wage } \\
\hline Inactive & 44 & 26.04 & 6 & 6.74 \\
\hline Unemployed \& Searching & 27 & 15.98 & 12 & 13.48 \\
\hline Self-employed & 33 & 19.53 & 24 & 26.97 \\
\hline Contract Wage & 65 & 38.46 & 47 & 52.81 \\
\hline Total & 169 & 100 & 89 & 100 \\
\hline \multicolumn{5}{|l|}{ v. Switched out of Self-employment } \\
\hline Inactive & 41 & 39.81 & 7 & 12.5 \\
\hline Unemployed \& Searching & 14 & 13.59 & 9 & 16.07 \\
\hline Non-Contract Wage & 24 & 23.3 & 19 & 33.93 \\
\hline Contract Wage & 24 & 23.3 & 21 & 37.5 \\
\hline Total & 103 & 100 & 56 & 100 \\
\hline \multicolumn{5}{|l|}{ vi. Switched out of Contract Wage } \\
\hline Inactive & 24 & 17.02 & 6 & 6.74 \\
\hline Unemployed \& Searching & 33 & 23.4 & 24 & 26.97 \\
\hline Non-Contract Wage & 54 & 38.3 & 33 & 37.08 \\
\hline Self-employed & 30 & 21.28 & 26 & 29.21 \\
\hline Total & 141 & 100 & 89 & 100 \\
\hline
\end{tabular}


Table 6. Variables Used in Analysis of Labor Market Transitions

\begin{tabular}{|c|c|}
\hline Variable & Description \\
\hline LSTATPR & $\begin{array}{l}\text { Labor market status in the PRIESO } 1999 / 2000 \text {, taking the value } 0-5 \text { for each sector, } \\
\text { unemployment and inactivity (dependent variable) }\end{array}$ \\
\hline HEAD & Dummy $=1$ if head of household \\
\hline MARRIED & Dummy $=1$ if married during the CASEN 1998 \\
\hline RURAL & Dummy $=1$ if \\
\hline NYKIDS & Number of kids age $0-9$ in the household \\
\hline NKIDS & Number of kids age $10-13$ in the household \\
\hline AGE & Age at the time of the CASEN 1998 \\
\hline YEDU & Years of education \\
\hline COLLAT & $\begin{array}{l}\text { Dummy = } 1 \text { if owned own home, another home or rental property ten years prior to } \\
\text { PRIESO (in 1990) }\end{array}$ \\
\hline NOTHSEL & Number of other household members who are self-employed \\
\hline INAC98 & Dummy $=1$ if inactive during CASEN 1998, interacted with all variables above \\
\hline UNEM98 & Dummy = 1 if unemployed during CASEN 1998, interacted with all variables above \\
\hline CWRK98 & $\begin{array}{l}\text { Dummy = } 1 \text { if contract wage worker during CASEN 1998, interacted with all variables } \\
\text { above }\end{array}$ \\
\hline INFW98 & $\begin{array}{l}\text { Dummy = } 1 \text { if non-contract wage worker during CASEN 1998, interacted with all } \\
\text { variables above }\end{array}$ \\
\hline SELF98 & Dummy = 1 if self-employed during CASEN 1998, interacted with all variables above \\
\hline
\end{tabular}




\section{Table 7. Mean Age, Education, Collateral and Number of Self-employed Household Members, by Labor Market Status}

(December 1998 in rows, December 1999/January 2000 in columns)

\begin{tabular}{|c|c|c|c|c|c|}
\hline \multirow{2}{*}{\multicolumn{2}{|c|}{$\begin{array}{l}\text { December } 1998 \\
\text { (i) Age at time of PRIESO }\end{array}$}} & \multicolumn{3}{|c|}{ "December 1999/January 2000} & \multirow[b]{3}{*}{ Inactive } \\
\hline & & & & & \\
\hline & Contract & No Contract & Self-employed & Unemployed & \\
\hline Contract & 39.92 & 38.89 & 37.27 & 32.33 & 50.75 \\
\hline No contract & 34.63 & 36.27 & 40.08 & 40.33 & 44.44 \\
\hline Self-employed & 38.41 & 43.48 & 47.37 & 43.22 & 65.81 \\
\hline Unemployed & 30.23 & 28.53 & 39.06 & 35.90 & 42.80 \\
\hline Inactive & 31.89 & 27.30 & 48.56 & 29.50 & 53.40 \\
\hline \multicolumn{6}{|c|}{ (ii) Years of Education } \\
\hline & Contract & No Contract & Self-employed & Unemployed & Inactive \\
\hline Contract & 9.51 & 9.35 & 10.92 & 8.79 & 11.25 \\
\hline No contract & 8.17 & 8.27 & 8.46 & 7.67 & 9.89 \\
\hline Self-employed & 11.59 & 8.81 & 9.90 & 5.22 & 7.00 \\
\hline Unemployed & 8.82 & 8.80 & 8.83 & 9.80 & 9.00 \\
\hline Inactive & 10.50 & 9.70 & 9.69 & 10.23 & 8.14 \\
\hline \multicolumn{6}{|c|}{ (iii) Share who Held Collateral } \\
\hline & Contract & No Contract & Self-employed & Unemployed & Inactive \\
\hline Contract & 0.480 & 0.290 & 0.690 & 0.250 & 0.750 \\
\hline No contract & 0.310 & 0.460 & 0.440 & 0.500 & 0.444 \\
\hline Self-employed & 0.630 & 0.280 & 0.740 & 0.660 & 0.930 \\
\hline Unemployed & 0.273 & 0.200 & 0.500 & 0.300 & 0.400 \\
\hline Inactive & 0.270 & 0.050 & 0.560 & 0.180 & 0.550 \\
\hline \multicolumn{6}{|c|}{ (iv) Number of Other Self-employed in the Household } \\
\hline & Contract & No Contract & Self-employed & Unemployed & Inactive \\
\hline Contract & 0.119 & 0.135 & 0.192 & 0.125 & 0.125 \\
\hline No contract & 0.229 & 0.100 & 0.240 & 0.080 & 0.220 \\
\hline Self-employed & 0.090 & 0.381 & 0.311 & 0.220 & 0.125 \\
\hline Unemployed & 0.270 & 0.200 & 0.050 & 0.100 & 0.200 \\
\hline Inactive & 0.440 & 0.200 & 0.380 & 0.410 & 0.220 \\
\hline
\end{tabular}




\section{Table 8. Multinomial Logit on Labor Market Transitions from December 1998 to December 1999/January 2000}

(Omitted Category: Contract Workers in December 1999/January 2000)

\begin{tabular}{|c|c|c|c|c|c|c|}
\hline & \multicolumn{2}{|c|}{ Unemployed 1999/2000 } & \multicolumn{2}{|c|}{ NC Employed 1999/2000 } & \multicolumn{2}{|c|}{ SSelf-employed 1999/2000 } \\
\hline & Coefficient & Std. Err. & Coefficient & Std. Err. & Coefficient & Std. Err. \\
\hline INFW98 & -5.449 & $(5.902)$ & 0.955 & $(2.911)$ & 0.146 & $(3.963)$ \\
\hline SELF98 & -20.638 & . & -5.270 & $(4.379)$ & -1.914 & $(4.314)$ \\
\hline UNEMP98 & -11.824 & $(9.966)$ & 3.096 & $(4.622)$ & 0.906 & $(5.897)$ \\
\hline INAC98 & 8.929 & $(4.157)^{* *}$ & 1.901 & $(3.244)$ & 4.409 & (3.914) \\
\hline \multicolumn{7}{|l|}{ Contract 1998} \\
\hline HEAD & -0.615 & $(0.564)$ & -0.149 & $(0.543)$ & -0.804 & $(0.748)$ \\
\hline MARRIED & -1.006 & $(0.574)^{*}$ & 0.121 & $(0.445)$ & 1.193 & $(0.698)^{*}$ \\
\hline RURAL & 0.351 & $(0.565)$ & 0.166 & $(0.475)$ & 0.939 & $(0.517)^{*}$ \\
\hline NYKIDS & -0.041 & $(0.271)$ & 0.000 & $(0.209)$ & -0.135 & $(0.271)$ \\
\hline NKIDS & -1.243 & $(0.703)^{*}$ & -0.069 & $(0.322)$ & -0.066 & $(0.362)$ \\
\hline AGE & 0.237 & $(0.190)$ & -0.120 & $(0.084)$ & 0.003 & $(0.150)$ \\
\hline $\mathrm{AGE}^{2}$ & -0.004 & $(0.003)$ & 0.001 & $(0.001)$ & 0.000 & $(0.002)$ \\
\hline YEDU & -0.111 & $(0.064)^{*}$ & 0.000 & $(0.051)$ & 0.098 & $(0.062)$ \\
\hline COLLAT & -0.374 & $(0.549)$ & -0.758 & $(0.421)^{*}$ & 0.956 & $(0.495)^{* *}$ \\
\hline NOTHSEL & -0.509 & $(0.611)$ & 0.023 & $(0.472)$ & 0.509 & $(0.501)$ \\
\hline \multicolumn{7}{|c|}{ Non-Contract 1998} \\
\hline HEAD & -0.434 & $(1.702)$ & 0.425 & $(1.407)$ & -0.008 & (1.609) \\
\hline MARRIED & 0.561 & $(1.823)$ & -0.470 & $(1.931)$ & -1.003 & $(1.512)$ \\
\hline RURAL & -2.518 & $(1.270)$ & -0.927 & $(1.004)$ & 0.404 & $(1.015)$ \\
\hline NYKIDS & -0.550 & $(0.636)$ & -0.228 & $(0.620)$ & 0.273 & $(0.586)$ \\
\hline NKIDS & 0.702 & $(0.995)$ & 1.895 & $(0.955)^{* *}$ & -0.955 & (1.336) \\
\hline AGE & -0.214 & $(0.126)^{*}$ & -0.040 & $(0.152)$ & -0.126 & $(0.130)$ \\
\hline $\mathrm{AGE}^{2}$ & 0.002 & $(0.002)$ & 0.000 & $(0.002)$ & 0.002 & $(0.002)$ \\
\hline YEDU & -0.109 & $(0.124)$ & -0.125 & $(0.137)$ & 0.061 & $(0.121)$ \\
\hline COLLAT & -0.659 & (1.313) & -1.709 & $(1.741)$ & -0.549 & $(1.488)$ \\
\hline NOTHSEL & 0.153 & $(0.568)$ & -0.905 & $(0.731)$ & 0.118 & $(0.641)$ \\
\hline \multicolumn{7}{|c|}{ Self-employed 1998} \\
\hline HEAD & 24.259 & $(7.348)^{* * *}$ & 1.673 & $(1.251)$ & 1.152 & $(0.930)$ \\
\hline MARRIED & -0.854 & $(1.176)$ & -1.667 & $(0.956)^{*}$ & -0.341 & $(0.795)$ \\
\hline RURAL & -1.965 & $(1.584)$ & 0.837 & $(0.973)$ & 0.303 & $(0.766)$ \\
\hline NYKIDS & 0.137 & $(0.566)$ & -0.218 & $(0.419)$ & -0.020 & $(0.270)$ \\
\hline NKIDS & -0.635 & $(1.028)$ & 0.836 & $(0.654)$ & -0.037 & $(0.521)$ \\
\hline AGE & 0.238 & $(0.271)$ & 0.210 & $(0.168)$ & 0.288 & $(0.138)^{* *}$ \\
\hline $\mathrm{AGE}^{2}$ & -0.003 & $(0.003)$ & -0.001 & $(0.002)$ & -0.002 & $(0.001)^{*}$ \\
\hline YEDU & -0.481 & $(0.153)^{* * *}$ & -0.089 & $(0.090)$ & -0.074 & $(0.065)$ \\
\hline COLLAT & -0.719 & $(1.047)$ & -2.437 & $(0.864)^{* * *}$ & -0.264 & $(0.625)$ \\
\hline NOTHSEL & 2.785 & $(1.262)^{* *}$ & 1.713 & $(1.033)^{*}$ & 2.064 & $(0.925)^{* *}$ \\
\hline Number of obs & \multicolumn{2}{|c|}{866} & & & & \\
\hline Log likelihood & \multicolumn{2}{|c|}{-696.275} & & & & \\
\hline LR $\chi^{2}(177)$ & \multicolumn{2}{|c|}{652.880} & & & & \\
\hline Prob $>\chi^{2}$ & \multicolumn{2}{|c|}{0.000} & & & & \\
\hline Pseudo $\mathrm{R}^{2}$ & \multicolumn{2}{|c|}{0.319} & & & & \\
\hline
\end{tabular}

“***” statistically significant at $1 \%$; “**” at $5 \%$; and “*” at $10 \%$ 
Table 8 (Continued from Previous Page).

\section{Multinomial Logit on Labor Market Transitions from December 1998 \\ to December 1999/January 2000}

(Omitted Category: Contract Workers in December 1999/January 2000)

\begin{tabular}{|c|c|c|c|c|c|c|}
\hline & \multicolumn{2}{|c|}{ "Unemployed 1999/2000 } & \multicolumn{2}{|c|}{ "NC Employed 1999/2000 } & \multicolumn{2}{|c|}{ Self-employed 1999/2000 } \\
\hline & Coefficient & Std. Err. & Coefficient & Std. Err. & Coefficient & Std. Err. \\
\hline \multicolumn{7}{|c|}{ Unemployed 1998} \\
\hline HEAD & -0.731 & (1.396) & 0.433 & (1.204) & 1.804 & (1.393) \\
\hline MARRIED & -0.317 & (1.489) & -0.906 & (1.323) & -1.997 & $(1.322)$ \\
\hline RURAL & -30.793 & $(4 . E+06)$ & -0.723 & $(1.458)$ & 0.313 & (1.174) \\
\hline NYKIDS & 0.445 & $(0.492)$ & 0.265 & $(0.449)$ & 0.898 & $(0.454)^{* *}$ \\
\hline NKIDS & -0.656 & $(1.147)$ & -1.012 & $(0.835)$ & 0.767 & $(0.766)$ \\
\hline AGE & 0.698 & $(0.523)$ & -0.165 & $(0.229)$ & -0.077 & $(0.276)$ \\
\hline $\mathrm{AGE}^{2}$ & -0.008 & $(0.007)$ & 0.002 & $(0.003)$ & 0.003 & $(0.003)$ \\
\hline YEDU & 0.099 & $(0.119)$ & -0.053 & $(0.106)$ & 0.131 & $(0.110)$ \\
\hline COLLAT & -0.453 & $(1.040)$ & -0.183 & $(0.912)$ & 0.229 & $(0.971)$ \\
\hline NOTHSEL & -0.550 & $(1.147)$ & -0.714 & $(0.903)$ & -3.173 & $(2.658)$ \\
\hline \multicolumn{7}{|l|}{ Inactive 1998} \\
\hline HEAD & -0.434 & $(1.702)$ & 0.425 & $(1.407)$ & -0.008 & (1.609) \\
\hline MARRIED & 0.561 & (1.823) & -0.470 & (1.931) & -1.003 & $(1.512)$ \\
\hline RURAL & -2.518 & $(1.270)^{* *}$ & -0.927 & (1.004) & 0.404 & (1.015) \\
\hline NYKIDS & -0.550 & $(0.636)$ & -0.228 & $(0.620)$ & 0.273 & $(0.586)$ \\
\hline NKIDS & 0.702 & $(0.995)$ & 1.895 & $(0.955)^{* *}$ & -0.955 & $(1.336)$ \\
\hline AGE & -0.214 & $(0.126)^{*}$ & -0.040 & $(0.152)$ & -0.126 & $(0.130)$ \\
\hline $\mathrm{AGE}^{2}$ & 0.002 & $(0.002)$ & 0.000 & $(0.002)$ & 0.002 & $(0.002)$ \\
\hline YEDU & -0.109 & $(0.124)$ & -0.125 & $(0.137)$ & 0.061 & $(0.121)$ \\
\hline COLLAT & -0.659 & (1.313) & -1.709 & (1.741) & -0.549 & (1.488) \\
\hline NOTHSEL & 0.153 & $(0.568)$ & -0.905 & $(0.731)$ & 0.118 & $(0.641)$ \\
\hline Number of obs & \multicolumn{2}{|c|}{866} & & & & \\
\hline Log likelihood & \multicolumn{2}{|c|}{-696.275} & & & & \\
\hline LR $\chi^{2}(177)$ & \multicolumn{2}{|c|}{652.880} & & & & \\
\hline Prob $>\chi^{2}$ & \multicolumn{2}{|c|}{0.000} & & & & \\
\hline Pseudo $\mathrm{R}^{2}$ & \multicolumn{2}{|c|}{0.319} & & & & \\
\hline
\end{tabular}


Appendix

\section{The Heckman-Lee Correction for Sample Selection Bias: An Application to Sector Choice in Chile}

Much of the literature on sector choice, especially in developing countries, relies on traditional cross-section analysis of wage differentials, corrected for possible sample selection bias. In this appendix, I apply the same methodology to analyze labor market insertion in Chile, estimate earnings differentials and discuss the strengths and weaknesses of this approach.

This appendix has three sections. Section A.I presents the Heckman (1979) two-step method, and the innovations on the method made by Lee (1983). Section A.II presents the results of the Heckman-Lee procedure, first on the entire sample of male workers in Greater Metropolitan Santiago from the CASEN 1998, and then on a sample restricted to employees with and without a legal employment contract. Section A.III concludes with a word of warning about analysis of earnings differentials and the two-step procedure.

\section{A.I. Approach and Hypotheses}

Using a two-stage procedure, I estimate sample selection terms that then enter into earnings equations. For Chile, I model three employment types: a "formal sector" of contract-wage employed (subscript, $c w$ ); and an "informal sector" made up of non-contract wage employed (nc), and self-employment (se). ${ }^{24}$ A Mincerian earnings equation is given by

$$
Y_{j i}=\beta_{j} X_{j i}+u_{j i}
$$

where $Y$ is earned take-home income, $j$ denotes the three employment types (cw, nc, and se), and $i$ represents the $i^{\text {th }}$ worker; $\beta$ is a vector of estimated parameters; $X$ is a vector of exogenous variables that determine earnings, including individual and household characteristics, experience, endowment of human capital, and characteristics of the place of employment; $u$ is a disturbance term.

\footnotetext{
24 As shown empirically in Yamada (1996) and Maloney (1998a), it is not sufficient to simply lump noncontracted wage employees with the self-employed in a single "informal-sector" category. F tests show that the two groups of workers are (statistically) significantly different with respect to several variables in the selection model, notably age, number of dependent children, and their holdings of human capital.
} 
If workers in each of the three employment types shared the same characteristics, OLS estimates would be unbiased. However, if individuals with unobservable characteristics (such as greater tolerance for risk, a desire for independence, or entrepreneurial talent) select into self-employment, the sample of self-employed would not be a random draw from the population, and OLS estimates would be inconsistent. Heckman (1979) proposes a two-stage procedure where the probability of selection into each employment type is estimated first by using a discrete choice model. Let $z^{*}$ be a continuous, unobserved variable which determines choice of employment type.

$$
z^{*}=\gamma W_{i}+\varepsilon_{i}
$$

where $W$ is a vector of exogenous variables which influence where individuals choose to work, and $\gamma$ is a vector of coefficients and $\varepsilon \sim N\left(0, \sigma_{\varepsilon}^{2}\right)$. If there is any correlation between the unobserved influences on choice of employment type (captured in $\varepsilon_{i}$ ) and the unobserved influences on earnings (captured in $u_{i}$ ), OLS estimates of the earnings function will be biased. Following Heckman (1979), I assume that $\varepsilon_{i}$ and $u_{i}$ are jointly distributed as a bivariate normal distribution. Thus the selection term $\lambda$, is the inverse of the Mills ratio, computed from the probabilities of employment type, and expressed

$$
\lambda=\phi\left(\gamma W / \sigma_{\varepsilon}\right) / \Phi\left(\gamma W / \sigma_{\varepsilon}\right)
$$

where $\phi$ is the standard normal density function, and $\Phi$ is the cumulative normal distribution function. The selection term $\lambda$ is then included as an additional regressor in the earnings equation, as follows.

$$
Y_{j i}=\beta_{j} X_{j i}+c_{j} \lambda_{j i}+u_{j i}
$$

The coefficient $c_{j}$ on $\lambda_{j i}$ will be a measure of the bias arising from non-random sample selection.

The Heckman (1979) correction is most often used to model binary choices. Since I am modeling the choice between three different employment types, ${ }^{25}$ an unordered multinomial

\footnotetext{
${ }^{25}$ Additional estimations included economic inactivity and unemployment, raising the number of categories to five.
} 
probit would be ideal, but computationally cumbersome. Lee (1983) proposes a transformation, used by Kingdon (1996), to calculate inverse Mills ratios from a selection equation specified as a multinomial logit. ${ }^{26}$

Lee (1983) explains that the probability of selection into a particular sector, $\Phi(\gamma W)$, can be obtained from a multinomial logit model. $\quad \phi(\gamma W)$ is evaluated at the inverse of the standard normal cumulative distribution function at this estimated probability. To estimate $\lambda$, the multinomial logit is estimated, and the coefficients and full set of predicted probabilities are retained. Taking the observations that have selected into a particular sector - say, selfemployment $-\lambda_{s e}$ is computed by first taking the predicted probability $P_{s e}$ and then $H_{s e, i}=\Phi^{-1}\left(P_{s e, i}\right)$, the inverse of the standard normal cumulative distribution function evaluated at the probability that observation $i$ selects self-employment. $\lambda_{\text {se }}$ can then be estimated as $\lambda_{s e}=\phi\left(H_{s e, i}\right) / \Phi\left(H_{s e, i}\right)$.

From the discussion of competing views of labor markets in developing countries in the text, if self-employment is part of the residual half of a dualistic labor market in Chile and the selfemployed are simply queuing along with the unemployed in the hope for an opening in the formal sector, we would expect the predicted earnings of the self-employed to be significantly less than those of salaried workers. We would further expect the coefficient on $\lambda_{\text {se }}$ in the earnings equation of the self-employed to be negative or not statistically significant. ${ }^{27}$ On the other hand, if workers with unobservable traits that lead them to succeed as entrepreneurs systematically choose self-employment, the coefficient on $\lambda_{\text {se }}$ should be positive.

Further, if formal salaried (contract) employment in Chile is rationed and workers in informal (non-contract) employment are queuing for formal jobs, we would expect the coefficient on $\lambda_{n c}$ in the earnings equation to be negative. Alternatively, if a significant number of informal employees choose non-contract employment - and lower earnings in the sector reflect the opportunity costs of a decision to keep investing in human capital while they work, the costs

\footnotetext{
${ }^{26}$ I am grateful to Dr. Geeta Kingdon and Dr. William Greene at New York University for providing both guidance and assistance in conducting this procedure.

${ }^{27}$ The estimated coefficient on the selection term might not be statistically significant if, for example, entry into self-employment is determined by access to capital to cover start-up costs.
} 
to employers of offering job training, or other apprenticeship arrangements - the coefficient on $\lambda_{n c}$ would either be positive or not significantly different from zero. The hypotheses to be tested with the Heckman-Lee procedure are formally summarized below.

\begin{tabular}{lll}
\hline \hline Ceteris paribus... & Null & Alternative \\
\hline $\begin{array}{l}\text { 1. Do the self-employed earn competitive incomes } \\
\text { relative to formal salaried workers? }\end{array}$ & $H_{0}: \hat{y}_{s e}-\hat{y}_{c w}<0$ & $H_{1}: \hat{y}_{s e}-\hat{y}_{c w} \geq 0$ \\
$\begin{array}{l}\text { 2. Do individuals with unobservable characteristics }- \\
\text { that positively determine entrepreneurial earnings - }\end{array}$ & $H_{0}: c_{s e}=0$ & $H_{1}: c_{s e}>0$ \\
systematically select into self-employment? & \\
$\begin{array}{l}\text { 3. Do workers choose the informal (non-contracted) } \\
\text { wage employment (or are they rationed out of } \\
\text { otherjobs)? }\end{array}$ & $H_{0}: c_{n c}<0$ & \\
\hline \hline
\end{tabular}

Tests of the hypotheses presented above will give some indication of whether workers enter the informal sector by chance or by choice. However, Maloney (2000) points out that studies that rely solely on earnings differentials - even controlling for sample selection bias - cannot prove or disprove either characterization of the labor market. Wage differentials fail to capture the value of unmeasured characteristics of different kinds of work, such as non-wage benefits, compensation for risk, independence, greater flexibility, in-kind payments, or implicit training costs. Maloney (2000) stresses that the magnitude of the distortion-free differential cannot be known beforehand, and hence researchers have no benchmark against which to compare segmentation. Just as the premium for entering formal salaried work or self-employment does not imply that either sector is superior or that workers queue for jobs in the higher paying sector, the discount on earnings in informal employment cannot be taken as conclusive evidence that the sector is inferior.

\section{A.II. Determinants of Earnings in Contract Employment, Self-employment, and Employment Without a Contract}

The sample for the first part of this analysis is taken from the CASEN 1998, and consists of male respondents between the ages of fourteen and 65 from Greater Metropolitan Santiago who were employed at the time of the survey. ${ }^{28}$ The definitions of the variables used in each

\footnotetext{
${ }^{28}$ I chose a male sample because of the well known and documented differences in the labor supply decisions and earnings equations for men and women. Similar studies (Taylor, 1996, Yamada, 1996, Maloney, 1998a \& 1998b, Pages \& Montenegro, 1999) also limited analysis to a male sample. I further limited the sample to respondents from Santiago in order to ensure comparability with the PRIESO sample. Running the same model
} 
step are given in Table A.1. All of the variables included are those traditionally employed in the Heckman-Lee procedure. For the first step, these include age and its square, individual and household characteristics (whether the respondent is head of household, married, the number of younger and older dependent children, and whether the respondent resides in a rural area), and variables for highest level of educational attainment. In the second step, variables determining earnings also include age and its square as proxies for experience, whether the respondent is married, ${ }^{29}$ educational attainment, the rural dummy and the size of the firm in which the respondent works. The only exceptional variable requiring explanation (included in the first step) is NOTHSEL - the number of household members other than the respondent who declare themselves as self-employed. ${ }^{30}$ I include this variable in the selection equation specifically to test the apprenticeship hypotheses of non-contracted employment namely, that a greater number of self-employed in the household increases the opportunities for informal apprenticeships for younger household members.

The results of the Heckman-Lee procedure are presented in Tables A.2 and A.3. The (omitted) reference category are contract employees - the "formal sector" workers in this analysis. This specification captures significant differences between the two branches of the informal sector and formal salaried employment. ${ }^{31}$

With respect to contract employees, those without a contract are likely to be younger, In contrast, the self-employed are likely to be significantly older than contract workers. Aroca and Maloney (1999) similarly find that self-employed workers in Mexico tend to be older, and argue that in developing economies where capital markets are distorted or missing and where

on all male respondents to the CASEN did not change the sign or significance on the estimated coefficients. Inactive male respondents - those not employed, nor searching for a job - were excluded after tests showed that they were significantly different from the unemployed with respect to age, position in the household and educational attainment.

${ }^{29}$ In many labor markets marriage is seen as a sign of stability and commitment, and is often rewarded with a salary premium.

${ }^{30}$ This variable is discussed at length earlier.

${ }^{31}$ In an alternative specification of the sector choice model (step one of the Heckman-Lee procedure), I used the unemployed as the reference category to captures significant differences between those employed in each of the three sectors, and those still searching for a job. The results show that workers in both branches of the informal sector are significantly different from the unemployed. Compared with the unemployed, non-contract workers have attained lower levels of education. In contrast, the self-employed are more likely than those still searching for a job to have completed primary, secondary and university education. 
there is little access to credit, only older workers have had sufficient time to amass the capital (or collateral for a loan) necessary to start their own business.

Workers without a contract are less likely to be married or heads of household. On the other hand, the self-employed are more likely than contract workers to be heads of household. However, the self-employed are significantly less likely to be married, which may indicate that self-employment is prevalent among single men and those with fewer dependent household members. This said, the number of younger (0 to 9$)$ and older (10 - 13) children in the household - included to capture the consideration of dependent family members in workers' decisions between employment options with different degrees of income risks - have no significant effect on the likelihood of self-employment. Non-contract workers, on the other hand, are significantly more likely to come from households with a larger number of older children.

Living in rural areas increases the probability of employment without a contract, but seems to have no effect on the likelihood that the respondent is self-employed. This last finding seems surprising since one might expect a large number of self-employed in rural farming. However, farming in Chile has rapidly grown out of the traditional model of household enterprise on small family-owned plots of land, and into a larger scale export industry, dramatically changing the allocation of labor between the sectors in rural areas (Thomas, 1996).

Compared to those with a contract, non-contracted workers are less educated. This finding can be interpreted either negatively - i.e. that a lack of educational attainment is acting as a barrier between these workers and the relative security of a contract - or positively - i.e. that an informal, flexible arrangement is preferred while these workers are still accumulating human capital, in the form of further study, experience and specific job skills. Compared to contract-wage workers, the self-employed are more likely to be heads of household but less likely to be married. Further, the self-employed are less likely than contract workers to have studied beyond secondary education. This is consistent with other studies that show few returns to the self-employed from formal education beyond secondary school (Taylor 1996).

The most interesting result in the first stage equations, is the strong significance of the number of other self-employed in the household on the sector in which the respondent works. Compared to contract workers, the self-employed have a higher number of other household 
members who also say they are running their own business. This could indicate either that several household members are being declared as independently self-employed even if they work in the same household enterprise, or it may be evidence of entrepreneurial traits shared among family members. ${ }^{32}$ Evidence of entrepreneurial traits passed between generations in the same family has been found by Taylor (1996) and Blanchflower and Oswald (1998). The number of other household members in self-employment not only significantly increases the probability that the respondent has their own business, but also increases the probability that the respondent is working as an employee without a contract. Given the relative youth of non-contract wage workers, this may be further evidence of apprenticeships offered by family members who own their own businesses.

Turning to the second-stage earnings equations in Table A.3, the estimated coefficients on the Mincerian variables controlling for workers' experience (proxied by AGE and AGE2) and their endowment of human capital, where significant, bear the expected signs. The coefficient on $\lambda_{\text {se }}$ indicates that there is significant (10\%) positive selection into self-employment in Santiago, similar to that found by Yamada (1996) in Lima. The coefficient on $\lambda_{\text {se }}$ may be capturing the influence of unobservable tolerance for risk, entrepreneurial talent, and/or desire for independence - or indeed any other omitted variable that is positively affecting the earnings performance of the sample in self-employment. The coefficient on the sample selection term for non-contract employment is also positive and significant (5\%). This result is somewhat surprising given the significantly lower hourly earnings of workers without a contract, but provides further evidence to support the apprenticeship hypothesis. ${ }^{33}$

The mean predicted hourly earnings (corrected for sample selection bias and dissagregated by respondents' highest educational attainment), are presented in Table A.4. The results of the correction for sample selection bias indicate that, all else equal, the self-employed can earn up to twice as much as contracted wage employees. Readers will note that the positive earnings differentials between self and contract employment hold even when unadjusted earnings are

\footnotetext{
${ }^{32}$ The way the survey interview is conducted is important to interpreting this result. Rather than conduct several interviews in the same household, numerators receive information on each household member form a single spokesperson. This single informant is usually the spouse of the household head. Gathering data from a single spokesperson lowers the likelihood that household members who work in the same household enterprise are incorrectly coded as independently self-employed.
} 
used in the two-step procedure, for all but the category of workers with incomplete primary education.

However, these results should be interpreted with extreme caution. I found the results of the Heckman-Lee procedure to be very unstable. While the two step procedure performed on a sample of all male respondents to the CASEN (nationally and in Santiago) shows significant positive selection into self-employment and non-contract wage employment, the result is not robust to changes in the sample or a reduction in the sample size. When I include men searching for employment in the procedure, the coefficient on the selection term into selfemployment is no longer significant. When I restrict the CASEN sample to responses from the 935 men of working age who would respond to the PRIESO twelve months later, the coefficients on the selection terms remained positive, but were no longer significant. Repeating the model on the sample of PRIESO respondents, but this time using data from the second survey, the estimated coefficients on the selection terms for non-contract employment and self-employment were both negative, but neither was statistically significant. This might be due partially to the smaller sample size, and to the significantly more adverse macroeconomic and labor market conditions at the time of the PRIESO. Furthermore, as discussed at length the CASEN survey may systematically over-state the earnings of the selfemployed by failing to separate profit from revenue. The survey does not take account of the costs of operating a business, nor do the rest of the questions in the labor module allow researchers to net-out the returns to physical capital.

In order to test the robustness of the positive selection term in the earnings equation of workers employed without a contract, I repeat the Heckman-Lee procedure, but this time exclude the self-employed for whom the earnings data are suspect and might have biased earlier results. Both steps of the Heckman-Lee procedure are shown in Table A.5. In the first step, a probit equation takes a dummy, equal to 1 if the respondent is employed without a contract and 0 with a contract, as the dependent variable. The estimated coefficients in the selection equation do not differ greatly from those in the multinomial logit in the first column in Table A.2, and remain significant at the same confidence levels. The only significant different between the estimated coefficients in the first column of Table A.5 and the earlier

\footnotetext{
33 There was no difference in the size and signs of the coefficients on any of the regressors (except the intercept) nor on the selection terms, when the earnings of the self-employed were "unadjusted" (that is, divided by 1.955 a reversal of the adjustment for under-reporting).
} 
selection equation, is that completing tertiary education significantly lowers the likelihood of employment without a contract at the $1 \%$ confidence level. In the multinomial logit, tertiary education had no significant effect on the likelihood of employment without a contract.

In contrast, the estimated coefficients in the second-step earnings equation in Table A.5, differ greatly with those for the earnings of workers without a contract in Table A.3. While not significant in the earlier specification, the estimated coefficients on age, its square, and the dummy variables controlling for whether the respondent completed primary, some secondary and a full secondary education are all statistically significant. However, the most important difference between the two specifications of the earnings equations for workers without a contract, is that the coefficient on the selection term $\lambda$ - positive and significant at $5 \%$ in Table A.3 - is no longer significantly different from zero, with a p-value of 0.985 . This result contradicts the findings discussed above, and weakens the argument that workers might choose employment without a contract.

\section{A.III. Conclusion}

Using a Heckman-Lee two-step procedure to correct for sample selection bias, I find positive sample selection into self-employment and employment without a contract in a cross section of workers in 1998. Although I find positive sample selection, this may be capturing any number of unobservable traits that positively determine earnings performance. In Barr and Packard (2002), economic experiments and hypothetical questions designed to measure risk aversion and time preference, show that the self-employed are not significantly different from employees with respect to these two unobservable parameters. The positive selection into self-employment discussed in this Appendix might reflect any number of unobservable traits, such as flexibility, motivation, entrepreneurial ability and a greater desire for independence. Similarly, positive selection into informal wage employment may be evidence of an apprenticeship mechanism at work.

However, the results of the Heckman-Lee procedure do not stand up to even small changes in the sample. Nor do the results stand when the procedure is conducted on the same sample of workers from one year to the next. While the Heckman-Lee two-stage techniques are powerful tools for capturing unobserved, individual characteristics that may be correlated with both sector choice and earnings, they are criticized for yielding unstable results and for 
being sensitive to the choice of model in the first-step selection equation (Manski, 1989, Maloney, 1998a, Puhani, 2000). Heckman (1979) warns that the two-step method depends critically on having confidence in the underlying model of how workers choose among the sectors, and that if this model is incorrect, the procedure can actually introduce more biases than it corrects. The analysis in this Appendix shows that a cross-section examination of earnings differentials, traditionally employed to examine sector choice, cannot on its own provide sufficient evidence of how the labor market functions to adequately inform social insurance policy. 
Table A.1. Variables Included in Heckman-Lee, Two-Step Procedure

\begin{tabular}{|c|c|c|c|}
\hline Variable & Description & In Step I & In Step II \\
\hline AGE & Respondents age & yes & yes \\
\hline AGE2 & Quadratic of AGE & yes & yes \\
\hline HEAD & Dummy $=1$ if head of household & yes & no \\
\hline MARRIED & Dummy $=1$ if married & yes & yes \\
\hline NYKIDS & Number of kids age $0-9$ in the household & yes & no \\
\hline NKIDS & Number of kids age $10-13$ in the household & yes & no \\
\hline NOTHSEL & Number of other household members who are self-employed & yes & no \\
\hline RURAL & Dummy $=1$ if resides in rural area & yes & yes \\
\hline INCPRIM & $\begin{array}{l}\text { Dummy = } 1 \text { if some primary school is highest educational } \\
\text { attainment }\end{array}$ & yes & yes \\
\hline PRIM & $\begin{array}{l}\text { Dummy = } 1 \text { if completed primary school is highest educational } \\
\text { attainment }\end{array}$ & yes & yes \\
\hline INCSEC & $\begin{array}{l}\text { Dummy = } 1 \text { if some secondary school is highest educational } \\
\text { attainment }\end{array}$ & yes & yes \\
\hline SEC & $\begin{array}{l}\text { Dummy = } 1 \text { if completed secondary school is highest } \\
\text { educational attainment }\end{array}$ & yes & yes \\
\hline INCTER & Dummy $=1$ if some university is highest educational attainment & yes & yes \\
\hline TER & $\begin{array}{l}\text { Dummy = } 1 \text { if completed university is highest educational } \\
\text { attainment }\end{array}$ & yes & yes \\
\hline FSIZE & Number of workers in place of work & no & yes \\
\hline
\end{tabular}


Table A.2. Sector Choice Equation, Male Respondents to the CASEN 1998, Greater Metropolitan Santiago

\begin{tabular}{|c|c|c|}
\hline \multirow[b]{2}{*}{ Selection into... } & \multicolumn{2}{|c|}{ Omitted Category: Contract Wage } \\
\hline & No-Contract Employment & Self-employment \\
\hline Constant & $\begin{array}{l}1.455 \\
(0.253)^{* * *}\end{array}$ & $\begin{array}{l}-3.080 \\
(0.274)^{* * *}\end{array}$ \\
\hline AGE & $\begin{array}{l}-0.094 \\
(0.014)^{* * *}\end{array}$ & $\begin{array}{l}0.071 \\
(0.014)^{* * *}\end{array}$ \\
\hline AGE2 & $\begin{array}{l}0.001 \\
(0.000)^{* * *}\end{array}$ & $\begin{array}{l}0.000 \\
(0.000)^{* *}\end{array}$ \\
\hline HEAD & $\begin{array}{l}-0.068 \\
(0.072)\end{array}$ & $\begin{array}{l}0.351 \\
(0.067)^{* * *}\end{array}$ \\
\hline MARRIED & $\begin{array}{l}-0.491 \\
(0.066)^{* * *}\end{array}$ & $\begin{array}{l}-0.272 \\
(0.057)^{* * *}\end{array}$ \\
\hline NYKIDS & $\begin{array}{l}0.005 \\
(0.029)\end{array}$ & $\begin{array}{l}-0.030 \\
(0.026)\end{array}$ \\
\hline NKIDS & $\begin{array}{l}0.142 \\
(0.044)^{* * *}\end{array}$ & $\begin{array}{l}0.030 \\
(0.040)\end{array}$ \\
\hline RURAL & $\begin{array}{l}0.358 \\
(0.064)^{* * *}\end{array}$ & $\begin{array}{l}-0.070 \\
(0.064)\end{array}$ \\
\hline PRIM & $\begin{array}{l}-0.292 \\
(0.087)^{* * *}\end{array}$ & $\begin{array}{l}0.029 \\
(0.082)\end{array}$ \\
\hline INCSEC & $\begin{array}{l}-0.481 \\
(0.077)^{* * *}\end{array}$ & $\begin{array}{l}-0.098 \\
(0.072)\end{array}$ \\
\hline SEC & $\begin{array}{l}-1.058 \\
(0.078)^{* * *}\end{array}$ & $\begin{array}{l}-0.324 \\
(0.068)^{* * *}\end{array}$ \\
\hline INCTER & $\begin{array}{l}-1.030 \\
(0.098)^{* * *}\end{array}$ & $\begin{array}{l}-0.353 \\
(0.083)^{* * *}\end{array}$ \\
\hline TER & $\begin{array}{l}-1.506 \\
(0.150)\end{array}$ & $\begin{array}{l}-0.210 \\
(0.089)^{* *}\end{array}$ \\
\hline NOTHSEL & $\begin{array}{l}0.161 \\
(0.057)^{* * *}\end{array}$ & $\begin{array}{l}0.922 \\
(0.045)^{* * *}\end{array}$ \\
\hline No. Obs. & 2083 & 3040 \\
\hline Total Obs. & 12494 & \\
\hline Log Likelihood & -11026.3 & \\
\hline$\chi^{2}[26]^{* * *}$ & 1783.24 & \\
\hline
\end{tabular}

Standard errors in parentheses

“***” statistically significant at $1 \%$; “**” at $5 \%$; and “*” at $10 \%$ 
Table A.3. Earnings Equations Corrected for Sample Selection Bias

\begin{tabular}{lcc}
\hline \hline & No-Contract Employment & Self-employment \\
\hline \multirow{2}{*}{ Constant } & 5.633 & \\
& $(0.129)^{* * *}$ & 5.654 \\
AGE & 0.000 & $(0.213)^{* * *}$ \\
AGE2 & $(0.012)$ & 0.046 \\
& 0.000 & $(0.008)^{* * *}$ \\
MARRIED & $(0.000)$ & 0.000 \\
& -0.019 & $(0.000)^{* * *}$ \\
PRIM & $(0.055)$ & 0.099 \\
& 0.017 & $(0.032)^{* * *}$ \\
INCSEC & $(0.053)$ & 0.188 \\
& 0.041 & $(0.051)^{* * *}$ \\
SEC & $(0.060)$ & 0.302 \\
& 0.053 & $(0.045)^{* * *}$ \\
INCTER & $(0.106)$ & 0.505 \\
& 0.431 & $(0.042)^{* * *}$ \\
TER & $(0.109)^{* * *}$ & 1.010 \\
& 0.998 & $(0.053)^{* * *}$ \\
RURAL & $(0.168)^{* * *}$ & 1.787 \\
& -0.096 & $(0.056)^{* * *}$ \\
FSIZE & $(0.050)^{*}$ & -0.234 \\
& 0.000 & $(0.040)^{* * *}$ \\
$\lambda$ & $(0.000)$ & 0.003 \\
& 0.543 & $(0.000)^{* * *}$ \\
& $(0.226)^{* *}$ & 0.119 \\
No. of Obs. & & $(0.064)^{*}$ \\
$\rho$ & 1896 & 2928 \\
\hline \hline & 0.24 & 0.36 \\
& 0.80 & 0.15 \\
& & \\
\hline
\end{tabular}

Standard errors in parentheses

“***” statistically significant at $1 \%$; “**” at $5 \%$; and “*” at $10 \%$ 
Table A.4. Predicted Hourly Earnings, and Earnings Differentials

Corrected for Sample Selection Bias

\begin{tabular}{|c|c|c|c|c|c|c|c|}
\hline & \multicolumn{4}{|c|}{ Predicted Hourly Earnings, 1998} & \multicolumn{3}{|c|}{ Predicted Differentials } \\
\hline & \multirow[t]{2}{*}{$\begin{array}{l}\text { Contract worker } \\
\text { (cw) }\end{array}$} & \multirow[t]{2}{*}{$\begin{array}{l}\text { Non contract worker } \\
\text { (nc) }\end{array}$} & \multicolumn{2}{|c|}{$\begin{array}{l}\text { Self-employed } \\
\text { (se) }\end{array}$} & \multicolumn{2}{|c|}{ se - cw } & \multirow[t]{2}{*}{ cw-nc } \\
\hline & & & (i) & (ii) & (i) & (ii) & \\
\hline Some Primary & 547.047 & 297.038 & 1040.693 & 532.003 & 493.646 & -15.045 & 250.010 \\
\hline Complete Primary & 598.893 & 316.438 & 1196.580 & 610.840 & 597.687 & 11.948 & 282.455 \\
\hline Some Secondary & 651.698 & 329.262 & 1363.917 & 696.838 & 712.219 & 45.140 & 322.436 \\
\hline Complete Secondary & 803.453 & 362.859 & 1809.369 & 919.071 & 1005.916 & 115.618 & 440.594 \\
\hline Some Terciary & 1177.938 & 516.830 & 3046.619 & 1549.718 & 1868.681 & 371.780 & 661.108 \\
\hline Complete Terciary & 3055.027 & 981.961 & 7679.537 & 3893.239 & 4624.509 & 838.211 & 2073.067 \\
\hline All Sample & 790.731 & 377.030 & 1704.637 & 868.696 & 913.905 & 77.965 & 413.701 \\
\hline
\end{tabular}

(i) Uses adjusted earnings

(ii) Uses unadjusted earnings 
Table A.5. Heckman-Lee Procedure on Contract and Non-Contract Employment

\begin{tabular}{|c|c|c|}
\hline & \multicolumn{2}{|l|}{ Omitted Category: Contract Employment } \\
\hline & Step 1 & Step 2 \\
\hline & $\begin{array}{c}\text { Selection Into Non-Contract } \\
\text { Employment } \\
\end{array}$ & $\begin{array}{c}\text { Earnings of Non-Contract } \\
\text { Employed } \\
\end{array}$ \\
\hline \multirow[t]{2}{*}{ Constant } & 1.630 & 5.702 \\
\hline & $(0.261)^{* * *}$ & $(0.121)^{* * *}$ \\
\hline \multirow[t]{2}{*}{ AGE } & -0.101 & 0.024 \\
\hline & $(0.015)^{* * *}$ & $(0.012)^{* *}$ \\
\hline \multirow[t]{2}{*}{$\mathrm{AGE}^{2}$} & 0.001 & $-2.5 \mathrm{E}-04$ \\
\hline & $(1.8 \mathrm{E}-04)^{* * *}$ & $(1.3 \mathrm{E}-04)^{*}$ \\
\hline \multirow[t]{2}{*}{ HEAD } & -0.063 & \\
\hline & $(0.072)$ & \\
\hline \multirow[t]{2}{*}{ MARRIED } & -0.485 & 0.088 \\
\hline & $(0.067)^{* * *}$ & $(0.057)$ \\
\hline \multirow[t]{2}{*}{ NYKIDS } & -0.003 & \\
\hline & $(0.029)$ & \\
\hline \multirow[t]{2}{*}{ NKIDS } & 0.150 & \\
\hline & $(0.044)^{* * *}$ & \\
\hline \multirow[t]{2}{*}{ RURAL } & 0.347 & -0.186 \\
\hline & $(0.065)^{* * *}$ & $(0.044)^{* * *}$ \\
\hline \multirow[t]{2}{*}{ PRIM } & -0.297 & 0.084 \\
\hline & $(0.088)^{* * *}$ & $(0.050)^{*}$ \\
\hline \multirow[t]{2}{*}{ INCSEC } & -0.501 & 0.148 \\
\hline & $(0.078)^{* * *}$ & $(0.062)^{* *}$ \\
\hline \multirow[t]{2}{*}{ SEC } & -1.097 & 0.284 \\
\hline & $(0.080)^{* * *}$ & $(0.111)^{* * *}$ \\
\hline \multirow[t]{2}{*}{ INCTER } & -1.083 & 0.655 \\
\hline & $(0.099)^{* * *}$ & $(0.113)^{* * *}$ \\
\hline \multirow[t]{2}{*}{ TER } & -1.531 & 1.337 \\
\hline & $(0.151)^{* * *}$ & $(0.168)^{* * *}$ \\
\hline \multirow[t]{2}{*}{ NOTHSEL } & 0.205 & \\
\hline & $(0.057)^{* * *}$ & \\
\hline \multirow[t]{2}{*}{ FSIZE } & & 2.2E-04 \\
\hline & & (2.0E-04) \\
\hline \multirow[t]{2}{*}{$\lambda$} & & 0.011 \\
\hline & & $(0.216)$ \\
\hline No of Obs. & 2083 & \\
\hline Total Obs. & 9454 & \\
\hline Log Likelihood & -4597.809 & \\
\hline$\chi^{2}[13]^{* * *}$ & 775.050 & \\
\hline $\mathrm{R}^{2}$ & & 0.233 \\
\hline$\rho$ & & $2.0 \mathrm{E}-02$ \\
\hline
\end{tabular}

Standard errors in parentheses

“***” statistically significant at $1 \%$; “**” at $5 \%$; and “*” at $10 \%$ 